\title{
Gestión forestal, necesidad naval y conflictividad jurídico- institucional: la Monarquía Hispánica y las instituciones vascas durante los Austrias
}

\author{
Alfredo José Martínez González \\ Profesor Asociado Doctor de Historia del Derecho \\ Universidad de Sevilla
}

\begin{abstract}
«Todos los días pasados tengo escripto a V.M. dando quenta (...) de lo que esta señalado y Repartido para los plantíos de robles y fresnos a las Villas y lugares de la costa desta provincia y la contradicion que han querido poner en nombre de Guipuzcoa para suplicar a V.M. que no se entienda con ellos tomando por ocasion que en la rreparticion que hize hauia señalado demasiado y no seria razón que se diese lugar a que se escusen de plantar conforme como esta Repartido. V.M. mandase pues importa tanto a su rreal seruicio y particular Bien y hutilidad de toda esta Tierra».
\end{abstract}

\begin{abstract}
Sumario: 1. Introducción.-2. Desarrollo y expansión de las superintendencias de montes y plantíos en las áreas vascas. 2.1. Antecedentes: política exterior, normas internas. 2.2. Primeras medidas: la creación de la superintendencia de montes y plantíos. 2.3. La fragmentación territorial. Auge y declive de las superintendencias vizcaína y guipuzcoana.-3. Análisis sistemático: la diversidad de legislaciones e instituciones forestales en los territorios vascos. 3.1. Vizcaya. 3.2. Guipúzcoa. 3.3. Efectos en el bien jurídico a proteger: agotamiento de las masas forestales. - 4. Conclusiones.
\end{abstract}

\section{INTRODUCCIÓN}

Las palabras con las que comenzamos el presente estudio reflejan la desesperación de un comisionado regio por intentar gestionar ciertas masas forestales vascas intentando conciliar los requerimientos de la Corona con las necesidades de los lugareños, ambos relacionados con la explotación de los bosques, aunque con finalidades bien distintas. Esta dicotomía fue una constante durante siglos que protagonizó una Historia forestal deslindada desde una múltiple perspectiva, jurídica, institucional, marítima y de relaciones entre la Monarquía Católica y ciertos territorios.

Ancestralmente la figura del monte se ha venido interrelacionando de manera íntima con el modus vivendi de sus pobladores: en sus áreas han vegetado tradicionalmente especies arbóreas, de matorral, herbáceas y arbustivas. En muchos casos se han desarrollado espontáneamente, pero en 
otro gran número han resultado consecuencia de cultivos desarrollados por los vecinos de los municipios circundantes como arraigado modo de subsistencia. Ello ha llevado a que desde antaño se hayan regulado las más diversas relaciones entre los lugareños y sus masas forestales adyacentes. Ahora bien, tal regulación no ha sido única. Han existido multitud de figuras jurídicas empleadas entre los pobladores y sus montes; a la par que éstas no siempre se ha mantenido impertérritamente sino que se han visto modeladas, desarrolladas e, incluso, erradicadas en función de las distintas épocas por las que inevitablemente han pasado y, concretamente en la Edad Moderna, a estas necesidades hubieron de añadírsele los requerimientos navales. La Monarquía Hispánica era perfectamente consciente de la importancia económica y política que suponían las extensiones arbóreas y el interés por los bosques se reflejó en el establecimiento de una serie de medidas políticas y legislativas de gran trascendencia destinadas al desarrollo del arbolado con fines bélicos-náuticos desde el siglo XVI. Estas necesidades sociales, por un lado, y navales por otro no fueron sino el reflejo de dos mundos que terminaron encontrándose en todo el arco cantábrico: por un lado, un universo silvícola habitado por sociedades rústicas en las que sus instituciones locales, de estructura y administraciones con pervivencia medieval, eran las más próximas al campesinado y tenían un peso específico en los asuntos forestales en los que sus habitantes se encontraban inmersos. Frente a ellas una política de arbolados que intentó sobreponerse a aquellas formas de gobierno provenientes de siglos anteriores y que en consecuencia terminó relacionándose, frecuentemente colisionando, con derechos provinciales o locales. Mediante este nuevo régimen de Montes la Monarquía Hispánica pretendió hacerse con el control y explotación de las masas boscosas del norte peninsular, como expondremos las más codiciadas, cuyo arbolado tenía una calidad que resultaba estratégica para la política marítima de la Corona pues, no debe soslayarse, buena parte de las relaciones exteriores hispánicas se basaron en la guerra naval.

Son pocos y exiguos los estudios que sobre esta materia existen a nivel histórico y además han sido generalmente desarrollados por personas ajenas al mundo del Derecho, muchos de ellos afamados técnicos forestales, por lo que consideramos se hace más que necesaria una investigación sobre este asunto desde el punto de vista histórico-jurídico. Así pues, el leitmotiv de esta investigación es el análisis, tanto cronológico como sistemático, de la base legal e institucional de una explotación de los bosques en favor de las necesidades navales, haciendo especial hincapié en cómo incidió en los territorios vascos a lo largo de buena parte de la Edad Moderna. Gran parte de la documentación archivística analizada ha permanecido inédita hasta ahora, habiéndose consultado fondos provenientes de los Archivos General de Simancas, General de Indias y del Museo Naval de Madrid. Los expedientes apuntan a que tal política marítima-forestal fue principalmente protagonizada por las Superintendencias de Montes y Plantíos, actuando a lo largo 
de casi dos siglos, con mayor o menor intensidad y acierto, en todo el norte peninsular. Es por ello que el esquema que seguiremos nos ha hecho estructurar esta exposición en dos bloques complementarios. En el primero, correspondiente al epígrafe número 2 , hemos tratado del desarrollo histórico de la institución «reconstruyendo» las instituciones silvícolas a través de la información archivística y contextualizándolas gracias a los datos aportados por la Historiografía (general y jurídica). En esta parte se ha pretendido exponer cuál fue el devenir de las mismas en los territorios vascos, desde sus antecedentes y nacimiento hasta su ocaso, estableciendo un vínculo de continuidad desde el siglo XVI hasta su definitiva erradicación. Respecto a la segunda parte, tratada en el tercer apartado, hemos analizado sistemáticamente los factores jurídico-institucionales, además de tanto las implantaciones como las ejecuciones de las normas, que no sólo atendieron a factores jurídicos sino también a factores extra o metajurídicos como fueron políticos, sociales y económicos.

Resulta importante resaltar que bajo la gestión forestal protagonizada por las Superintendencias y su correspondiente normativa descansó sustancialmente todo el entramado naval de una Monarquía que, por Universal, se veía obligada no sólo a salvaguardar las costas peninsulares sino también a preparar y mantener la defensa de unos espacios que se encontraban en Europa, África, América y el Pacífico ${ }^{1}$. El asunto, con un claro trasfondo político que pretendía preservar la economía e integridad territorial de los enclaves hispánicos mediante la fortaleza marítima, giraba constantemente alrededor de aspectos jurídicos.

Las Superintendencias de Montes, diseñadas por Felipe II y que llegarán hasta el fin de la primera mitad del siglo $\mathrm{XVIII}^{2}$, pretendieron romper con una arraigada tradición de colectivismo silvícola. En este mundo rural, hasta entonces, la costumbre había jugado -y siguió jugando en contraposición a los requerimientos de la Corona- un importante papel como fuente jurídica. Sin embargo, a sensu contrario la Monarquía pretendió que los tratamientos consuetudinarios por los que tradicionalmente se habían venido gestionando los bosques quedasen supeditados a normas de origen regio, ya fuesen directamente provenientes del monarca o de sus órganos de gobierno o, mediante mecanismos de jurisdicción delegada, por los propios superintendentes. Será una historia de intentos por organizar una nueva vida jurídica, administrativa y política, en ocasiones con grandes fracasos y en otros momentos con importantes aciertos, que repercutieron frecuentemente tanto en la vida rural vasca como en sus instituciones.

${ }^{1}$ Mira Caballos, E., Las Armadas imperiales. La guerra en el mar en tiempos de Carlos Vy Felipe II, Ed. La Esfera de los Libros, Madrid, 2005, p. 173.

${ }^{2}$ Éstas serían erradicadas tácitamente, en plena dinastía borbónica, mediante la Real Ordenanza de Montes de Marina, de 31 de enero de 1748. 


\section{DESARROLLO Y EXPANSIÓN DE LAS SUPERINTENDEN- CIAS DE MONTES Y PLANTÍOS EN LAS ÁREAS VASCAS}

\subsection{Antecedentes: política exterior, normas internas}

Buena parte de las medidas forestales dentro de los territorios hispánicos vino de la mano de la política exterior de la Monarquía. Este asunto ha sido en gran medida desconocido por la historiografía, por lo que se hace necesario exponer, siquiera someramente, el tracto sucesivo de las Superintendencias en consonancia con los episodios navales de mayor relevancia, aunque dejaremos un volumen importante de la documentación archivística analizada para la segunda mitad de este trabajo, correspondiente al análisis sistemático.

En el siglo XVI las dimensiones de los territorios hispánicos eran tan extensas que fue la primera vez en la historia que una Monarquía se enfrentaba a una complejidad naval tan ingente, pues no sólo se trataba de salvaguardar las costas peninsulares sino igualmente de preparar y mantener la defensa de áreas que abarcaban desde Fuenterrabía hasta El Ferrol, de Barcelona a Nápoles, de Sevilla a Tierra Firme, o desde Nueva España a Filipinas ${ }^{3}$.

En la última década del reinado de Carlos I se detectan las primeras referencias conocidas acerca de la preocupación por parte de la Corona respecto a la protección de los montes destinados a la construcción de buques ${ }^{4}$. El interés forestal del emperador se manifestó al poco de su llegada a la península mediante una «Carta acordada de la Reina Juana y Carlos V, sobre plantación y repoblación de montes y pinares», fechada el 21 de mayo de $1518^{5}$. Esta disposición no atendió expresamente a las necesidades navales, pero sí recogió una iniciativa que en ciertos aspectos terminó proyectándose a ulteriores legislaciones empleadas para el fomento de la Marina siendo dirigida a municipios, señoríos y abadengos, para «remediar el mucho desorden por decepar y talar para pastos de ganados, e abrigos de ganados y leña e madera e carbon». De este modo, la Corona pretendió impulsar el «bien común de estos nuestros reynos e señorios», pues los múltiples re-

3 Mira Caballos, E., Las Armadas imperiales. La guerra en el mar en tiempos de Carlos Vy Felipe II, Ob. Cit., p. 173.

${ }^{4}$ Casado Soto, J. L., «Barcos para la guerra. Soporte de la Monarquía Hispánica» en Cuadernos de Historia Moderna., Anejo VI, Publicaciones de la Universidad Complutense, Madrid, 2006, pp. 30-31.

${ }^{5}$ AGS, Cámara de Castilla, DIV, 1, Doc. 84. La disposición fue recogida en la Novísima Libro VII, Título XXIV, Ley II y tratada por GIBERT y SÁNChEZ DE LA VEGA, R., «Ordenanzas Reales de Montes en Castilla (1496-1803)» en Actas del II Symposium de Historia de la Administración, Instituto de Estudios Administrativos, Madrid, 1971, pp. 312-314. Sin embargo, el documento hológrafo original hallado en el Archivo General de Simancas presenta alguna divergencia, que si bien es puntual, sí resulta notable. Por ejemplo, éste extiende sus disposiciones no sólo a terrenos de realengo o señorío, sino también de abadengo. 
cursos que proporcionaban las masas forestales eran fundamentales para la preservación e integridad de sus territorios. Pero será más tarde, en 1547, cuando empezamos a tener noticias del reconocimiento de lo que posteriormente será una constante: la relación entre la industria naval y el comienzo de la escasez de algunas masas boscosas. En aquel año se promulgó en Valladolid una disposición por parte del emperador y su madre, D. ' Juana, en la que se declaraba que tanto en la Provincia de Guipúzcoa como en el Señorío de Vizcaya habían existido cortas abusivas destinadas al suministro de tablones y maderamen para construcción naval y que la Corona no había sido ajena a la misma, reconociéndose los efectos negativos que éstas habían tenido en la región, propiciando una significante carestía de árboles en dichos territorios. Como medida para salvaguardar las masas forestales de estas áreas vascas se concedió un importante papel a las instituciones locales, aunque no quedaba especificado ningún sistema concreto de inspección, vigilancia e intervención en el control de las talas, sino tan sólo la obligación de remitir relaciones de lo efectuado en materia forestal al Consejo de Guerra, órgano de la administración central de la Monarquía Universal. Además, para fomentar los arbolados, se declaraba un régimen de compensación por cada corta mediante un sistema de plantíos que, aunque no detallaba el modo de sembrar ni injertar, sí exponía la necesidad de plantar el doble de lo talado. Por otro lado, la norma ostentaba una marcada eficacia retroactiva al establecer una obligación de restitutio in integrum de la masa arbórea en las zonas taladas por parte de aquellos cortadores que hubiesen llevado a cabo talas en un plazo de los diez últimos años a contar desde su promulgación ${ }^{6}$. En 1548 las Juntas Generales de Guipúzcoa abordaron también el grave problema de la deforestación. Concretamente, en la Junta General de Zumaya, celebrada en abril de aquel año, fue establecida una Ordenanza sobre plantíos que ordenaba a perpetuidad la obligación de plantar 500 pies de robles y castaños anuales ${ }^{7}$. Además los plantíos debían establecerse en suelos que reuniesen las condiciones más convenientes para su crecimiento, así como en zonas resguardadas de fuertes vientos. Por su parte, los alcaldes ordinarios tenían encomendada la tarea de hacer plantar los árboles, a costa de los propios concejos.

Aquella disposición obtendría confirmación real el 6 de junio de 1548 en Valladolid. A ella se le añadió en las Juntas Generales de Elgóibar una Ordenanza de 10 de mayo de 1552 , dirigida tanto a municipios como a particulares ${ }^{8}$. Ésta última también versaba sobre los remedios para evitar la deforestación de

\section{${ }^{6}$ Novísima Recopilación, Libro VII, título XXIV, ley VIII.}

7 Ordenanza sobre plantíos (1548), Juntas Generales de Zumaya, celebradas entre el 14 y el 24 de abril de 1548, 7 junta (A.G.G.-G.A.O., R 2) transcrita por ArAGón RUANO, A., El bosque guipuzcoano en la Edad Moderna: aprovechamiento, ordenamiento legal y conflictividad, Sociedad de Ciencias Aranzadi, San Sebastián, 2001, p. 188.

${ }^{8}$ Ésta sería más tarde confirmada por una Real Provisión de Carlos I dada en Madrid, 20 de diciembre de 1552. Transcrita en ibídem, pp. 189-191. Cita A.G.G.-G.A.O., 2/17/4. 
montes comunes y particulares, consecuencia entre otras causas de las «muchas e muy grandes carracas e naos e otras fustas con que su magestad se a seruido». En caso de incumplimiento recaía una pena de doscientos maravedíes por cada pie de roble, destinándose una mitad a la cámara real y la otra porción a repartir entre el juez y el denunciador a partes iguales. La medida principal consistía en obligar a quienes talasen, especialmente a los carboneros, a:

«dexar y dexen en los dichos montes xarales asi guiados para carbon de quarenta en quarenta codos vn roble guiado por roble grande y creçido y no le corten ni talen los tales dueños hasta que sea suficiente para madera de naos o casas»».

Poco después en las Juntas Generales de Deva, celebradas en noviembre de 1552, fue acordado que los plantíos estuvieran costeados por las villas, como sucedía con otros tipos de obras, tal era el caso de las calzadas o puentes, a través de «repartimientos». En esta misma asamblea se reguló el establecimiento de viveros que garantizasen la plantación de los árboles. La responsabilidad de éstos recaía en dichas villas, que debían registrar una relación sobre cómo se ejecutaban. En caso de incumplimiento, era el corregidor quien comprobaría el estado de los viveros ${ }^{9}$. Estas disposiciones adquirieron una especial importancia en favor de los astilleros vascos pues un año antes, en 1551, se había dispuesto mediante Real Orden que los barcos destinados a la Carrera de Indias no podrían ser construidos con maderas del sur peninsular, lo que afectó a la Maestranza de Sevilla, que hasta entonces había dispuesto de una excelente mano de obra muy cualificada ${ }^{10}$.

Lo cierto es que, pese a la falta de cohesión de la Armada carolina y de la existencia de ciertas talas que habían comenzado a yermar ciertos montes, el emperador disponía de la primera Marina más importante del mundo y la segunda en efectividad en cuanto a su organización, únicamente superada por la veneciana ${ }^{11}$. Pero tras su muerte, la complicada situación internacional

9 Aragón Ruano, A., «Labores forestales en Guipúzcoa durante los siglos XVIXVIII» en Zainak. Cuadernos de Antropología-Etnografia; n $^{\circ}$ 17, Eusko Ikaskuntza, San Sebastián, 1998, pp. 112-114.

${ }^{10}$ Cervera Pery, J., La Casa de Contratación y el Consejo de Indias (las razones de un superministerio), Ministerio de Defensa, Madrid, 1997, p. 166. Concretamente, especifica que la prohibición se refería a las áreas de Sevilla, Sanlúcar de Barrameda, Cádiz, Puerto de Santa María, Condado de Niebla, Marquesado de Gibraleón y Ayamonte. Esta prohibición legal tal vez se debiera a que las maderas del sur peninsular tenían una mayor amplitud en sus anillos anuales y presentaban una considerable nudosidad que las hacían menos aptas para los navíos de las rutas atlánticas. FERnÁNDEZ IzQUIERdo, F., «Astilleros y construcción naval anterior a la Ilustración» en España y el ultramar hispánico hasta la Ilustración, I Jornadas de Historia Marítima, Cuadernos Monográficos del Instituto de Historia y Cultura Naval, no 1, Instituto de Historia y Cultura Naval, Madrid, 1989, p. 4.

${ }^{11}$ De Bunes ibarra, M. A., «La defensa de la cristiandad; las armadas en el Mediterráneo en la Edad Moderna» en Cuadernos de Historia Moderna. Anejos V, Universidad Complutense, Madrid, 2006, pp. 81-82. 
con la que Felipe II se encontró vendría a evidenciar que los esfuerzos de su padre no habían sido suficientes ${ }^{12}$. El balance de enfrentamiento naval hispano-turco en la época de Carlos V había resultado manifiestamente desfavorable para el lado cristiano ${ }^{13}$. El heredero al trono fue consciente que para hacer frente a sus responsabilidades en los territorios ubicados a lo largo de tres continentes sólo sería capaz de efectuarlo erigiéndose como una gran potencia naval, por lo que se vio en la necesidad de construir y sostener una Marina que luchase en diversos conflictos. A este fin subordinó buena parte de su política tanto exterior como interna; pero como se acaba de apuntar, para desempeñar su liderazgo a escala mundial, no tuvo otro remedio que instrumentalizar la figura del barco para su expansión y control en unos años que coinciden con una fase de enorme aumento territorial de la Monarquía Hispánica ${ }^{14} \mathrm{y}$, en ese contexto, determinadas áreas vascas alcanzarían un especial protagonismo.

Todo indica que durante el extenso reinado de Felipe II, los asuntos navales evolucionaron de modo más acelerado que en épocas anteriores. Ello se debió en buena medida a sistemáticas decisiones tomadas por el monarca y sus Consejos que, además de ocuparse de múltiples aspectos relativos a la ingeniería naval, aumentaron constantemente la demanda de nuevas embarcaciones útiles para sostener las rutas marítimas, así como buscaron la manera de poner freno a las acciones del resto de potencias navales europeas. Hubo en este sentido una época que representó un punto de inflexión y tuvo lugar durante los años cincuenta del siglo XVI, tras la conocida como Paz de Catêau-Cambrèsis. ${ }^{15}$ Mediante este episodio fue cerrado medio siglo de

12 De Pazzis pi Corrales, M., La Armada de los Austrias (conferencia), Real Sociedad Económica Amigos del País, Valncia, 2001, p. 162.

${ }^{13}$ De Bunes Ibarra, M. A., "La defensa de la cristiandad; las Armadas en el Mediterráneo durante la Edad Moderna» en Cuadernos de Historia Moderna. Anejos V, Ob. Cit. p. 83.

${ }_{14}$ Valdez Buvnov, I., Naval Power and State Modernisation: Spanish Shipbuilding Policy in the Eighteenh Century, Tesis Doctoral leída y defendida en el Queen's College de la Universidad de Cambridge, 2000-2005, p. 13. De BordeJÉ y Morencos, F., «El poder naval en tiempos de Felipe II» en El Ejército y la Armada de Felipe II ente el IV centenario de su muerte (IV Jornadas de Historia Militar), Ministerio de Defensa. Secretaría General Técnica, Madrid, 1997, pp. 124-125. Condeminas Mascaró, F., La Marina militar española, Ed. Aljaima, Málaga, 2000, p. 145. Mira Caballos, E., Las Armadas imperiales. La guerra en el mar en tiempos de Carlos Vy Felipe II, Ob. Cit., pp. 124-125. CASAdo Soto, J. L., Los barcos de la expansión oceánica española, Conferencia pronunciada en la XVII Semana de Estudios del Mar, Asociación de estudios del Mar, Pontevedra, 2000. http://www.asesmar.org/conferencias/semana18/semana18.htm

${ }^{15}$ Barkham Huxley, M., «El comercio marítimo vizcaíno y guipuzcoano con el Atlántico peninsular (Asturias, Galicia, Portugal y Andalucía) y con los archipiélagos de Canarias y Madeira al principio de la Edad Moderna» en Itsas memoria. Revista de Estudios Marítimos del País Vasco, n 4, Untzi Museoa-Museo Naval, Donostia-San Sebastián, 2003, p. 158. Casado Soto, J. L., «Barcos para la guerra. Soporte de la Monarquía Hispánica» en Cuadernos de Historia Moderna., Anejo VI, Ob. Cit., p. 31. 
disputas bélicas entre las dinastías reinantes de las dos monarquías más poderosas de Europa, los Habsburgo en España y los Valois en Francia. El tratado aguantaría el paso del tiempo y el peso de la Corona francesa terminó decreciendo como resultado del acceso al trono, de modo sucesivo, de varios príncipes de carácter enfermizo. Como consecuencia Felipe II no se vio obligado en los primeros años de su reinado a hacer frente a los franceses, que hasta aquel entonces habían supuesto una de las principales preocupaciones de la Monarquía Católica en el terreno militar. El monarca pronto fue consciente que, tras decenios de luchas en tierra, entre las lindes de Italia y Francia, la atención bélica debía desplazarse a otro escenario: el mar ${ }^{16}$. El control de los océanos era de tal importancia estratégica que el establecimiento de «fuerzas navales permanentes» terminó siendo más significativo para la historia del siglo XVI de lo que fueron los denominados «ejércitos permanentes» y las primeras se convirtieron en un factor decisorio para el equilibrio de fuerzas tanto dentro como fuera del Viejo Continente, donde se estaba abriendo camino la hegemonía europea en aguas hasta entonces desconocidas ${ }^{17}$. Así lo hizo saber expresamente al declarar «lo que importa y conviene a mi serviçio y al bien de nuestros subditos que aya número de navíos en la mar destos reinos $\rangle^{18}$.

\subsection{Primeras medidas: la creación de la superintendencia de montes y plantíos}

Dada la importancia de la madera, fueron emprendidas toda una serie de medidas destinadas a impulsar una industria naval que respondiese a las crecientes necesidades que la Corona necesitaba. Dichas iniciativas se plasmaron en un conjunto de políticas y actuaciones concatenadas y coordinadas que abarcaron decisiones de gestión, técnicas, estructurales, económicas y legislativas que, iniciadas en torno a 1562, tuvieron como único objetivo dotar a la Monarquía de unas Armadas capaces de salvaguardar sus inmensos dominios. En este sentido, es significativo que ese mismo año Venecia nombrase embajador para tratar de la triple alianza con Felipe II y el Papado ${ }^{19}$. La Monarquía Hispánica debía llevar a cabo un plan de refuerzo naval acorde

${ }^{16}$ Goodman, D., El Poderío naval español. Historia de la Armada del siglo XVII, Ediciones Península, Barcelona, 2001, p. 19.

17 Thompson, I. A. A., «Las galeras en la política militar española en el Mediterráneo durante el siglo XVI» en Manuscrits, $\mathrm{n}^{\circ}$ 24, Departamento de Historia Moderna y Contemporánea de la Universidad Autónoma de Barcelona, Barcelona, 2006, p. 96. PARKer, G., La revolución militar. Innovación militar y apogeo de occidente (1500-1800), Ed. Alianza, Madrid, 2001, p. 120.

184 de mayo de 1563. Comisión encargada a Cristóbal de Barros para la promoción de construcciones navales en el norte. Trascripción del documento en CASADO Soto, J. L., Los barcos españoles del siglo XVI y la gran armada de 1588, Instituto de Historia y Cultura naval / Ed. San Martín, Madrid, 1988, p. 283.

${ }_{19}$ Domínguez Nafría, J. C., El Real y Supremo Consejo de Guerra (siglos XVI-XVIII), Centro de Estudios Políticos y Constitucionales, Madrid, 2001, p. 83. 
con la Santa Liga ${ }^{20}$. Una pieza clave en este extenso programa de construcción, armamentos y actividad astillera fue la intensificación de plantaciones de árboles y esta tarea resultó encomendada principalmente a un personaje, del que aún poco se conoce, pero que resultó crucial para la puesta en marcha de aquellas medidas: Cristóbal de Barros y Peralta.

Este oficial fue encargado de los asuntos navales y silvícolas, según el propio Felipe II, «desde primero de hebrero del año pasado de 1562, que fuisteis llamado por nos para el dicho negocio» ${ }^{21}$. Al poco de su nombramiento, Barros remitió al monarca un Memorial en el que reflejaba las carencias del entramado naval español y que habían llegado a culminar en una preocupante falta de barcos ${ }^{22}$. Para paliar esta situación se le confirió una enorme área de actuación que comprendía «la costa de la provincia de Guipúzcoa, señorío de Vizcaya, Quatro Villas de la Costa de la Mar, principado de Asturias y reino de Galizia» ${ }^{23}$. A lo largo de todos estos lugares debía emprender una serie de actividades destinadas a la inspección y valoración de la situación en la que se encontraban los efectivos navales, así como de las posibilidades que ofrecían diversas zonas para construir nuevos buques. Con este fin el monarca le encomendó expresamente, mediante Ynstrucciones promulgadas en Madrid, el 6 de mayo de 1563, el plantío de nuevos árboles que pudiesen servir a la Marina, actuando siempre mediante

${ }^{20}$ Pazzis pi Corrales, M., La Armada de los Austrias (conferencia), Ob. Cit., p. 162.

${ }^{21}$ AGS, G.A., Leg. 347-15. Ynstruizion que se dio a Xrobal de Barros sobre lo de los navios, Madrid, 6 de mayo de 1563.

${ }^{22}$ Sobre la existencia de este documento, no hemos hallado su original pero sí ha sido encontrada una «Relación de sacada del Memorial que Xptoual de Uarros dio cerca de lo que conuenia prouerse sobre la fabrica y conserucion de las naos y de los que a si mismo se dieron por parte delos dueños dellas y personas interesadas en el», AGS, G.A., Leg. 347-17. Por otra parte, el propio Barros redactó años más tarde lo que él mismo denominó como una «sustançia» del memorial que, aunque reconocía no ser literalmente el texto primigenio, sí era «cassi deste thenor». Éste último texto ha sido publicado por ENRIQUE Fernández, J. y Sesmero Cutanda, E., "Informes de Cristóbal de Barros y Esteban de Garibay sobre la construcción naval en la cornisa cantábrica (1569)» en Itsas memoria. Revista de Estudios Marítimos del País Vasco, no 3, Untzi Museoa-Museo Naval, Donostia-San Sebastián, 2000, p. 685. En él se recoge la trascripción del documento que se conserva en AHN, Cámara de Castilla, Serie Patronato Real, reg. 15651, leg. 1. Ninguno de los dos documentos aportan la fecha exacta de la composición, si bien ésta debió tener lugar entre el nombramiento de Barros, a comienzos de 1562, y con anterioridad al mes de mayo del siguiente año, como reconoce el propio comisionado en el último de los textos, p. 692. Tal era la carencia de barcos, que en el área cantábrica la Monarquía extenderá su veto no sólo a la exportación de maderas, sino también a la de navíos ya construidos tanto por la Corona como por particulares. AGS, G.A., Leg. 72-297 bis; Real Cédula. Escorial, 27 de agosto de 1568. También en AGS, G.A., Leg. 72-300, Real Provisión del año 1568.

${ }^{23}$ AGS, G.A., Leg. 347-15 y 16. Instrucción a Cristóbal de Barros sobre lo que ha de hacer en la Provincia de Guipúzcoa, Señorío de Vizcaya, etc. sobre la fabricación de naves, adobo, etc., etc. 
la acción conjunta con los representantes locales de Guipúzcoa, Vizcaya y las Cuatro Villas ${ }^{24}$ :

«Hablareis de nuestra parte a los corregidores de las dichas partes encargandoles lo que toca a las plantas de los montes, y en las juntas que para esto se hicieren os hallareis presente, donde les significareis lo que deseamos que esto aya efecto, por lo mucho que importa» ${ }^{25}$.

Estas Ynstrucciones, compelían a que los corregidores, jueces de residencia y justicias señalasen y repartiesen la cantidad anual de robles que estimasen oportuna, teniendo en cuenta tanto la calidad como la extensión de los terrenos. Una vez especificada la cuantía destinada a cada municipio, sus Justicias ordinarias y regidores debían hacer un reparto de árboles a costa de los bienes de propios del concejo y, a su vez, los corregidores estaban obligados a hacer una relación escrita de los robles asignados a todos los lugares, dejándose claro que aquellas labores forestales redundarían en el «bien publico» ${ }^{26}$. Así las cosas, el fomento forestal para la fábrica de navíos no resultaba ser una cuestión menor. Felipe II llegó a manifestar su preocupación en aquellos momentos porque «cada dia se reciben males y daños de los turcos y moros y otros corsarios que andan por la mar» ${ }^{27}$. La causa directa era una situación internacional que, aunque se encontraba lejos de las montañas del norte peninsular, preocupaba prioritariamente al monarca católico: desde el anterior reinado, en la década de 1520, el antiguo Mare Nostrum seguía siendo dominado navalmente por fuerzas islámicas en expansión de turcos otomanos y sus aliados, corsarios de la costa norte africana de Trípoli, Túnez y Argel que constantemente venían sembrando el terror en la costa levantina española y otras posesiones mediterráneas, a los que había que hacer frente. ${ }^{28}$ Así pues, la necesidad de incrementar los arbolados provenientes de la cornisa cantábrica se debía principalmente a la necesaria apertura del mar a la cristiandad. Se estaba gestando la creación de una Armada que a los pocos años culminaría con la batalla de Lepanto. ${ }^{29}$

${ }^{24}$ Rodríguez Fernández, A., Alcaldes y regidores. Administración territorial y gobierno municipal en Cantabria durante la Edad Moderna, Institución Cultural de Cantabria \& Ediciones Librería Estudio, Santander, 1986, p. 17. El término «Cuatro Villas de la costa del mar de Castilla» se refería al corregimiento que englobaba, a grandes rasgos, los municipios de Castro Urdiales, Santander, Laredo y San Vicente de la Barquera, además de otras áreas aledañas.

${ }^{25}$ Casado Soto, J. L., Los barcos españoles del siglo XVI y la gran armada de 1588 , Ob. Cit., p. 279.

${ }^{26}$ AGS, G.A., Leg. 347-19. Goodman, D., Poder y penuria. Gobierno, tecnología y ciencia en la España de Felipe II, Ed. Alianza Universidad, Madrid, 1990, p. 110.

${ }^{27}$ AGS, G.A., Leg. 72-300.

28 Goodman, D., El Poderío naval español. Historia de la Armada del siglo XVII, Ob. Cit., p. 19.

29 Enríquez Fernández, J. y Sesmero Cutanda, E., «Informes de Cristóbal de Barros y Esteban de Garibay sobre la construcción naval en la cornisa cantábrica (1569)» en Itsas 
Por ello, siendo consciente del poder de su adversario, y guiado por un meticuloso carácter, Don Felipe encargó recabar noticias exhaustivas sobre los recursos navales septentrionales con los que poder organizar sus escuadras ofensivas, además de prohibir la exportación de maderas a otros reinos ajenos a la Monarquía Católica. Una de estas peticiones para recoger informes fue la solicitada a Barros. Tal vez esta solicitud se efectuase por mediación de Hernán Suárez de Toledo, miembro del Consejo Real a quien el monarca le había ordenado coordinar, además de las cuestiones marítimas, las indagaciones sobre el funcionamiento de las Juntas y Corregimientos de la Provincia de Guipúzcoa y el Señorío de Vizcaya, con unas miras reformistas que obligaron a los dirigentes locales a enfrascarse en costosas y prolijas negociaciones al respecto. ${ }^{30}$ Ante la petición de pesquisas encargadas a Cristóbal de Barros, éste emitió un informe en 1569 que nos permite conocer algún contenido más concreto del modo con que desde la Corona pretendían fomentar los arbolados, pues expresamente declaraba:

«Que mandase su magestad que en la Probinzia de Guipuzcoa, Señorio de Vizcaya, Quatro Villas de la Costa de la Mar se planten montes desta manera: que todos los lugares que tubieren terminos a dos leguas de la mar y rios nabegables, e mas si la tierra fuere llana, sean obligados a plantar en cada un año señalada cantidad de robles por repartimiento quel corregidor haga en cada conçejo, considerada la cantidad y calidad de su termino, y que estos sean del tamaño y se planten en los tiempos que comvenga, y que los alcaldes y regidores de los lugares hagan otro repartimiento mas en particular al comun del conçejo e a cada vezino considerando la tierra y termino que posen; y que del un repartimiento y del otro el corregidor tenga un libro en que este asentados los robles que en cada un año se an de plantar en cada conçejo y que personas, y questos mesmos alcaldes tomen quenta en cada un año a los vezinos de lo que an plantado para que hellos mesmos la den al corregidor, el qual execute las penas en los que no ubieren plantado $»^{31}$.

Merece la pena detenerse en este documento debido a que refleja la necesidad de emplear esas corrientes de agua para nutrir de materias primas la construcción naval. En él se contiene el criterio de extender a lo largo de dos leguas la explotación forestal a zonas fluviales, debido a la posibilidad de transportar los troncos hasta la costa valiéndose de la flotación a través

memoria. Revista de Estudios Maritimos del País Vasco, no 3, Ob. Cit., p. 685.

${ }^{30}$ Enríquez Fernández, J. y Sesmero Cutanda, E., «Informes de Cristóbal de Barros y Esteban de Garibay sobre la construcción naval en la cornisa cantábrica (1569)» en Itsas memoria. Revista de Estudios Marítimos del País Vasco, nº 3, Ob. Cit., p. 686.

${ }^{31}$ Ibídem, p. 691. 
de sus cauces ${ }^{32}$, asunto éste que con posterioridad tendrá una importante trascendencia al vincular los terrenos ribereños del cantábrico a la jurisdicción de las futuras superintendencias.

En opinión de Barros debía seguir protegiéndose el arbolado, simultanear los replantes con las cortas que se organizasen y continuar señalando, tras haberse estudiado previamente, los lugares propicios para obtener los ejemplares más útiles. Para ello había visitado los puertos y astilleros del litoral, oído las quejas de los dirigentes de cada lugar, examinado sus fundamentaciones y reunido a personas entendidas en el arte de la industria naval ${ }^{33}$. Consecuentemente, su presencia era bien conocida por las autoridades de la zona que debía fiscalizar pero, sin embargo, su opinión sobre el cumplimiento que debían obedecer acerca de la obligación de colaborar con él por parte de quienes ostentaban las jurisdicciones locales de diversos territorios seguía sin ser por completo positiva; por ello se dirigió ante el propio rey Felipe en los siguientes términos:

«Que algunos corregidores de Guipuzcoa, Vizcaya e Quatro Villas no an cumplido las probisiones de los plantios y que en Asturias y Galizia combiene mucho se manden plantar, y que para que mejor se pudiese probeer se abisava a su magestad de las cossas que se contenian en un memorial que di. Aora que e bisto la costa puedo deçir a vuesa merçed que, aunque los corregidores no guardan la horden de la probision, todabia el aver platicado sobre ello como lo e hecho yo con muchas personas y en todos los lugares de la costa de Guipuzcoa e Vizcaya les a despertado mucho para entender quanto les ymporta; y va mas adelante e raçonablemente lo de los plantios en Guipuzcoa e Vizcaya $\rangle^{34}$.

Aún así, a pesar de las quejas por la posible falta de colaboración de algunas autoridades a la hora de efectuar los trabajos de plantaciones de nuevos ejemplares, la escasez de madera no era en aquellos momentos iniciales un problema que aún preocupase en exceso al comisionado regio, «porque en las montañas de Guipúzcoa y Vizcaya ay arta y adelante se puede dar orden que aya mucha mas $\rangle^{35}$.

32 Dicha práctica está acreditada en la península ibérica desde época romana: en el río Betis se reunían almadías, conformadas por un conjunto maderos unidos con otros, que eran conducidos fácilmente a flote desde el nacimiento del caudal hasta Hispalis. Vid. Almendral Lucas, J. M., "Caminos antiguos entre Cástulo y Córdoba» en Revista de Obras Públicas, $\mathrm{n}^{\circ}$ 3421, Colegio de Ingenieros de Caminos, Canales y Puertos, Madrid, Mayo 2002, p. 53.

33 Fernández Duro, C., A la mar madera. Libro Quinto de las Disquisiciones Náuticas, Imprenta de Aribau, Madrid, 1880, pp. 20-21.

34 Enríquez Fernández, J. y Sesmero Cutanda, E., «Informes de Cristóbal de Barros y Esteban de Garibay sobre la construcción naval en la cornisa cantábrica (1569)» en Itsas memoria. Revista de Estudios Marítimos del País Vasco, n 3, Ob. Cit., p. 703.

35 Ibídem. 
Poco después, mediante esta política naval y la alianza con la Santa Liga, la Corona tuvo que hacer frente a otro esfuerzo naval para aportar un total de ciento sesenta y cuatro buques destinados a luchar contra la escuadra otomana pocos años más tarde, que culminarían en 1571 con la destrucción de la flota de galeras turca en Lepanto por parte de la alianza entre el Papado, Venecia y España ${ }^{36}$.

La rapidez por impulsar la construcción de barcos de guerra tuvo correlativas consecuencias en los montes peninsulares y, en lo que a este análisis respecta, la Monarquía dio un paso más: el 7 de diciembre de 1574, Cristóbal de Barros fue nombrado formalmente como «Super Yntendente» de Montes y Plantíos para todo el cantábrico ${ }^{37}$. El cargo implicaba, por un lado, el fomento y conservación de los montes; y por el otro, todo lo referido a la construcción naval, incluyendo una ardua tarea, el acopio de maderas ${ }^{38}$. Tales maderas deberían ser norteñas, puesto que los tratados navales de la época reflejaban que de «Vizcaya» salían completos «galeones y galeazas, patajes, zabras para Armada hechizos fuertes como pertenecen para ofender $\mathrm{y}$ defender donde hay bastante madera ${ }^{39}$. El preámbulo del nombramiento

36 Thompson, I. A. A., «Las galeras en la política militar española en el Mediterráneo durante el siglo XVI» en Manuscrits, $\mathrm{n}^{\circ}$ 24, Ob. Cit., p. 98.

37 ASG, Leg. GA 347/57. Real Cédula de Felipe II, Tanto del titulo de xptobal de Varros. Para los Plantios de rrobles su besita y de montes y dehesas, Madrid, 7 de septiembre de 1574. Goodman, D., El Poderío naval español. Historia de la Armada del siglo XVII, Ob. Cit., p. 109 y 111. Gómez Rivero, R., «Aproximación a la Superintendencia en Guipúzcoa (s. XVII)» en Centralismo y Autonomismo en los siglos XVI-XVII, Servicio de Publicaciones de la Universidad de Barcelona, Barcelona, 1989, p. 161 (pie de pág. 2). Afirma sobre la institución de la Superintendencia: «Qué duda cabe que el vocablo superintendente surge en Francia. El primer superintendente que aparece en la administración central francesa es el de finanzas. Desde el siglo XIV, en Francia, las finanzas reales estaban divididas en ordinarias y extraordinarias que se administraban por los tesoreros y los generales». Orduña Rebollo, E., Intendentes e Intendencias, Ed. Tres Américas, Madrid, 1997, pp. 39-40 y 42. Fija el origen de los intendentes franceses en el siglo XVI, cuyo objetivo fundamental era colmar las pretensiones de los reyes por controlar todos los ámbitos de las administraciones. De entre ellos y a efectos de esta investigación, cita la aparición de unos «Comisarios de Ejército», encargados de la intendencia y administración militares, a quienes se les confería unos poderes muy amplios, sin determinaciones legales concisas, ostentando un poder discrecional cuyo límite formal sólo lo constituía la confianza del monarca. Al ser designados por éste y erigirse como Le Roi présent dans la province, sólo eran responsables ante el rey. HAROUEL ET AL, Histoire des institutions de l'epoque France à la Révolution, Presses Universitaires de France, Paris, 1987, p. 323. Timbal, P. C. y Cataldo, A., Histoire des institutions et des faits sociaux; Ed. Dalloz, Paris, 1979, pp. 378-379.

38 Gómez Rivero, R., «La Superintendencia de construcción naval y fomento forestal en Guipúzcoa (1598-1611)» en A.H.D.E., n 56, 1986; pp. 594-595. Aragón Ruano, A., El bosque guipuzcoano en la Edad Moderna: aprovechamiento, ordenamiento legal y conflictividad, Sociedad de Ciencias Aranzadi, San Sebastián, 2001, p. 47.

${ }_{39}$ Mena García, C., «Nuevos datos sobre bastimentos y envases en Armadas y flotas de la Carrera» en Revista de Indias, Vol. LXIV, núm. 231, 2004. Cita Archivo General de 
de Barros reflejaba que la demanda de árboles en la zona cantábrica había originado un fuerte incremento de los precios de la madera, lo que había provocado un declive en la industria naval. Para llevar a cabo sus cometidos gozaría de plena capacidad ejecutiva y se le ordenaba que hiciera cumplir rigurosamente las instrucciones y ordenanzas que se adjuntaban a su nombramiento ${ }^{40}$. Este asunto llegó a tener una enorme relevancia, pues las medidas con las que el superintendente quiso remediar la carencia de árboles útiles fueron tan importantes que a lo largo del siguiente siglo continuaron siendo básicamente las mismas ${ }^{41}$, regulándose la fiscalización de las cuentas municipales, la imposición de impuestos a los vecinos para sufragar plantaciones y la aportación de testimonios por cada uno de los municipios que reflejasen la plantación efectiva de ejemplares. También podía castigar «según y de la misma manera que lo pueden hazer los justicias» y se le confirió la autoridad necesaria para supervisar a los corregidores, informando al rey ante cualquier negligencia. El superintendente sólo respondía ante al monarca o los órganos centrales de la Monarquía y tanto a los corregidores como a las justicias se les dio orden de no interferir en su labor. Él mismo se ocupó de hacer los repartimientos en toda la cornisa cantábrica, desde la frontera del Bidasoa hasta la del Miño, exceptuándose los asignados a Vizcaya y Guipúzcoa, donde en la práctica los llevaron a cabo sus respectivos corregidores, quienes representando al rey formaban parte de sus Juntas, con el beneplácito posterior del propio Barros ${ }^{42}$.

Indias (AGI), Patronato, 269, R.17, 1.

40 AGS, GA, Leg. 78-108 y 377, Madrid, 7 de diciembre de 1574. Citado también por Casado Soto, J., Los barcos españoles del siglo XVI y la Gran Armada de 1588, Ob. Cit., p. 113.

${ }^{41}$ Goodman, D., El Poderío naval español. Historia de la Armada del siglo XVII, Ob. Cit., p. 109.

${ }^{42}$ Las reticencias a la actuación de cualquier comisionado real en las provincias vascas en detrimento de las competencias de sus instituciones serían frecuentes, entendiendo que con la intervención de los corregidores era suficiente. Así, por acuerdo de 28 de septiembre de 1574, en el Regimiento de Tierra Llana y Villas del Señorío de Vizcaya, había quedado reflejado que «Se tuvo aviso de que para todo el reino, se proveen Jueces de Escribanos y de comision contra las justicias y Regidores y fieles, para tomar cuentas de los propios y de su gasto y distribucion y como se ha entendido que lo mismo se ha hecho o se ha de hacer en este Señorio, teniendo en cuenta que los escribanos y Oficiales que han sido y son en el Señorio habian sido y eran muy leales, recto en sus oficios y tales que han usado y usan según y en la manera que están obligados como deben a Dios y Su majestad, y además la tierra estaba muy pobre y gastada mediante las guerras de flandes y Armada que se ha aprestado por mandato de Su majestad y que sería de gran inconveniente, ai a este Señorío viniese semejante Juez, pues en él hay Corregidor y veedor por Su Majestad, por quien se les ha tomado su residencia y son punidos y castigados los que han delinquido y delinquen; por lo cual acordaron se suplique a Su Majestad y al Ilmo. Presidente de España, no manden proveer ni enviar a este Señorío tal Juez; porque sería en notable daño del Señorío porque serían vejados y habría perjuicios y se cobrarían enemistades por odio y rencor, que algunos tuviesen contra otros». Acuerdos semejantes se producirán a lo largo del tiempo. Vid. De Sargarmínaga F. y de Areitio, D., El Gobierno y Régimen 
Por otro lado, le fue conferida la facultad de efectuar todo lo que considerase necesario y, en virtud de esta competencia, Barros elaboró una Instrucción en 1575 que sin duda alguna sentó las bases de toda la organización forestal posterior ${ }^{43}$. En ella se estableció el modo de plantar anualmente tanto desde el punto de vista técnico como sus consecuencias legales en caso de incumplimiento.

Ahora bien, su plena aplicación distó mucho de lograrse. En las Juntas provinciales de Guipúzcoa celebradas en Fuenterrabía y Vergara, durante aquel mismo año de 1575, y las Juntas Generales de Motrico en 1576, se insistió reiteradamente a las villas de la Provincia en su cumplimiento, lo que tácitamente demostraba que los viveros y plantíos no se ejecutaban según lo previsto $^{44}$. Por su parte, en Bilbao, por acuerdo del Regimiento, de 2 de agosto del mismo año, fue dispuesto, «conforme a lo que de antes está decretado» - lo que nos confirma que tampoco se venía respetando- que nadie pudiese adquirir para revender tablas ni maderas ${ }^{45}$. Esta decisión tenía su razón de ser, puesto que aunque las montañas de la Villa disponían de robles y otras especies adecuadas para reforzar y ensamblar cascos de los barcos, también competía por esta materia prima la industria siderúrgica vasca y que surtía a los constructores navales de clavos, anclas, cadenas y piezas de artillería para los buques, lo que no dejaba de ser paradójico ${ }^{46}$. Esta necesidad de maderas por otros sectores originó que poco después, en agosto de 1577, se enviasen múltiples despachos desde la Corte para que se obedeciese lo ordenado por la Superintendencia de Montes ${ }^{47}$. Consecuentemente, la asistencia de las instituciones locales, a pesar de ser fundamental, desde la perspectiva de Barros no llegaba a producirse como sería deseable, por lo que solicitó al rey que se siguiesen dando «provisiones muy bastantes» para adquirir toda la madera

Foral del Señorio de Vizcaya, Vol. I, Excma. Diputación Foral de Vizcaya, Bilbao, 1928, pp. 333-334, 381-382. Por su parte, Gónzález Alonso afirma que en el caso de Guipúzcoa el corregidor actuaba «defecto de la autoridad militar propiamente dicha». Vid. GonZÁLEZ Alonso, B., El Corregidor castellano (1348-1808), Instituto de Estudios Administrativos, Madrid, 1970, p. 228. Ayerbe IríBAR, Ma . R., «Las Juntas Generales vascas. En defensa de la foralidad y de los derechos históricos» en Ivs Fvgit, n 15, Universidad de Zaragoza, Zaragoza, 2007-2008, p. 305.

${ }^{43}$ ASG, G.A., Leg. 347/57, cédula de Felipe II, 7 de septiembre de 1574, Madrid. Se le otorgó el permiso de que «en lo que os Paresçiere combenir podays bos azer y ordenar todo».

${ }^{44}$ Aragón Ruano, A., El bosque guipuzcoano en la Edad Moderna: aprovechamiento, ordenamiento legal y conflictividad, Ob. Cit., p. 82.

45 De Sargarmínaga F. y de Areitio, D., El Gobierno y Régimen Foral del Señorio de Vizcaya, Vol. I, Ob. Cit., p. 453.

${ }^{46}$ Rahn Phillips, C., Seis galeones para el rey de España. La defensa imperial a principios del siglo XVII, Alianza Editorial, Madrid, 1991, p. 86.

${ }^{47}$ AGS, G.A., Leg. 82-220 a 232. 
que precisaba y mediante las que se obligase a las justicias a respetar puntualmente las decisiones del monarca ${ }^{48}$.

Con frecuencia las villas que no aportaban testimonios de sus plantíos durante la época en la que Barros estuvo al frente de la Superintendencia alegaban no disponer del terrenos suficientes para esta actividad, ya fuese porque sus bosques se encontraban densamente poblados o a causa de no tener apenas términos territoriales o fondos económicos ${ }^{49}$. En otras ocasiones podían disponer de terrenos pero se encontraban ocupados en su mayoría, quedando muy pocos por plantar a consecuencia de que muchos baldíos se destinaban al aprovechamiento ganadero e imposibilitados para plantíos ${ }^{50}$. Éste fue el caso de las poblaciones de Zumaya o Placencia, que habían quedado ahora al margen de la jurisdicción de Fernando de la Riva y, a pesar de las demandas de las Juntas Generales de Guipúzcoa (que podían reclamarlas) para que aportasen sus registros de plantaciones, quedaron relevadas de su obligación en 1583 «...por no tener términos libres en que hazer plantios ni propios con que hazerlos». Tampoco era normal, al menos en la provincia guipuzcoana, que las villas llevasen sus registros a tiempo siendo frecuente que se retrasase un año la aportación del testimonio que reflejase el cumplimiento con el mandato real. Ante esa situación la Provincia ejercía su autoridad, como ocurrió cuando en 1592 condenó al pago de 10.000 maravedíes a las villas de Tolosa, Mondragón, Vergara, Motrico, Elgóibar, Fuenterrabía, Guetaria, Zarauz, Elgueta, Úrsúbil, Placencia, Orio y el Valle Real de Léniz conminándoles a llevar el próximo año los testimonios de ese año y el siguiente $^{51}$.

En estas circunstancias, una de las mayores contribuciones no fue prestada por los municipios sino especialmente por un vecino de San Sebastián, Juan de Lasalde, quien en mayo de 1581 se ofreció a construir ocho navíos utilizando las arboledas de Rentería y dejando claro que «la tabla que sale destos montes es la mejor, con mucha ventaja, que hay en Guipúzcoa y Vizcaya», además de emplear para ciertas piezas con formas específicas otra gran cantidad de maderas procedentes de diversas jurisdicciones de quienes se solicitó que sus justicias ayudasen en todo lo que se les fuese ordena$\mathrm{do}^{52}$. Esta colaboración no había llegado a existir plenamente en materia de plantíos desde que éstos fueron implantados ya que en las Juntas Generales de Guetaria, celebradas del 14 al 24 de noviembre de 1580, se había hecho

48 Casado Soto, J. L., Los barcos españoles del siglo XVI y la gran armada de 1588 , Ob. Cit., p. 328. Cita a Archivo del Museo Naval (AMN) Col. Navarrete, t. 22, Fols. 302313, Santander, 13 de junio de 158.

49 Aragón Ruano, A., El bosque guipuzcoano en la Edad Moderna: aprovechamiento, ordenamiento legal y conflictividad, Ob. Cit., p. 69.

${ }^{50}$ Ibídem, p. 98.

51 Ibídem, p. 69.

52 AMN, Col. Navarrete, t. 22, Fols. 299-301. Rentería, mayo de 1581. AMN Col. Navarrete, t. 22, Fols. 302-313. Santander, 13 de junio de 1581. 
constar que las Instrucciones en materia de plantíos seguían sin aplicarse; por lo que es de suponer que las maderas que emplearía Lasalde serían nacidas de modo natural en sus montes y no como consecuencia de la acción de sus vecinos $^{53}$.

\subsection{La fragmentación territorial. Auge y declive de las superintenden- cias vizcaína y guipuzcoana}

Cristóbal de Barros permaneció oficialmente en el cargo de Superintendente de Montes y Plantíos hasta el año 1596 y entre esta fecha y 1598 la zona de actuación de la Superintendencia se fragmentó en diversas áreas que abarcaban, la provincia de Guipúzcoa, el Señorío de Vizcaya y AsturiasCuatro Villas ${ }^{54}$. Respecto a Galicia, su principal contribución a la formación de armadas no llegó a ser maderera sino más bien de aprovisionamiento de víveres $^{55}$. A pesar de que Barros cesaría nominalmente en el cargo en 1596, lo cierto es que desde 1592 estuvo frecuentemente inactivo en materia forestal como consecuencia de haber sido nombrado Proveedor de la Armada Guardacostas de la Carrera de Indias y destinado a Sevilla ${ }^{56}$.

En Guipúzcoa ${ }^{57}$, donde ya existía algún área esquilmada para obtener madera $^{58}$, los asuntos de montes recayeron en torno a 1597 sobre la figura de

${ }^{53}$ Aragón Ruano, A., El bosque guipuzcoano en la Edad Moderna: aprovechamiento, ordenamiento legal y conflictividad, Ob. Cit., p. 69.

${ }^{54}$ Goodman, D., El Poderío naval español. Historia de la Armada del siglo XVII, Ob. Cit., p. 369.

${ }_{55}$ SaAvedra Vázquez, M. C., «La formación de Armadas y sus efectos sobre el territorio: el ejemplo de Galicia, 1580-1640» en Cuadernos de Historia Moderna. Anejos V, Universidad Complutense, Madrid, 2006, p. 57.

56 Goodman, D., El Poderío naval español. Historia de la Armada del siglo XVII, Ob. Cit., p. 369.

${ }^{57}$ Ibídem, p. 369. Afirma que la Superintendencia de Urquiola tuvo sus comienzos en 1598. Esa misma fecha es la considerada por Gómez Rivero, R., «Aproximación a la Superintendencia en Guipúzcoa (s. XVII)» en Centralismo y Autonomismo en los siglos $X V I-X V I I, O b$. Cit., p. 162 y en «La Superintendencia de construcción naval y fomento forestal en Guipúzcoa (1598-1611)» en A.H.D.E., n ${ }^{\circ}$ 56, Ob. Cit., pp. 601-606, donde incluso se apunta como posible el mes de agosto de 1598. Por nuestra parte hemos encontrado documentos que indican como comienzo de su actividad forestal el año 1597 (AGS, Leg. 484-54, 490-106, 490-123, 490-127), aunque desconocemos si la misma empezó a llevarse a cabo sin haberse efectuado el nombramiento oficial como Superintendente, actuando simplemente dentro de sus competencias como general de la Armada.

${ }_{58}$ AGS, Leg. 484-54. Carta de Antonio de Urquiola a Felipe II. Pasajes, 25 de abril de 1597. Odriozola Oyarbide, L., «La construcción naval en Guipúzcoa. Siglos XVIXVIII» en Itsas Memoria. Revista de Estudios Marítimos del País Vasco, $\mathrm{n}^{\circ}$ 2, Untzi Museoa-Museo Naval, Donostia-San Sebastián, 1998, pp. 111-112; se cita cómo entre 1593-1594 se cortaron 400 robles en los montes de Rentería para la construcción de seis navíos, cantidad que la autora estimaba que debió ser mayor a pesar de no disponer de datos pues desde el primero de estos años hasta el presente de 1597 la actividad de los astilleros guipuzcoanos, especialmente los renterianos; y, en menos medida, de los vizcaínos, fue especialmente productiva, llegando a labrarse en esta población 29 galeones para las 
Antonio de Urquiola, director de los astilleros de Santiago (Urola) y Pasajes y constructor de navíos ${ }^{59}$, además de general de la escuadra de Cantabria. ${ }^{60}$ Se seguían precisando navíos en la costa vasca y debían acapararse con prontitud los materiales necesarios para construirlos en sus astilleros ${ }^{61}$. Un año antes, en 1596, la provincia también había podido comenzar a nutrirse de maderas navarras, donde la actividad naútica no era tan vital como en el área vasca $^{62}$.

Desde el inicio de su actividad no fueron infrecuentes las protestas del nuevo comisionado dirigidas al rey acerca de la falta de colaboración de las poblaciones locales en todo lo referente a la construcción naval, acusándoles de negarse a cooperar en el acarreo de la madera y que obligaron a Urquiola a elevar quejas alegando que «recaudo he ymbiado diversas bezes a guipuzcoa y al corregidora» $\sin$ obtener respuesta satisfactoria ${ }^{63}$. Las primeras fricciones entre el funcionario real y la provincia surgieron a consecuencia de la peste que se había propagado en una zona clave para la fábrica de navíos, la comprendida entre San Sebastián y Pasajes, «que es a menos de dos tiros de arcabuz de los astilleros $»^{64}$, y ante el riesgo

Armadas Reales. Por su parte, el Capitán Agustín de Ojeda, quien más tarde sería Superintendente en la costa vizcaína, tomó parte en aquella deforestación, dejando relación de maderas cortadas y la reticencia de la población local a participar de la corta sin mediar compensación económica, puesto que «...quando bine a esta Villa a principiar esta fabrica tomando platica delos montes della alle que no abia otro mas acomodado que un exido que tiene la misma Villa, que es el mejor que ay en toda esta provincia y tratando con la Justicia y regimientos della se hauia de cortar madera en el, no quisieron que se començasse sin obligarme a la paga y por facilitar el seruicio de V.m . y que no sse ynquietasen lo hize mediante esto sean cortado como quints. arboles, y sera menester cortar mas de otros cuatrocientos y últimamente no queria ya cortar ninguno hasta que se les pagase lo que se auia tomado cn buenas palabras ofreciendoles que del primer dinr ${ }^{\circ}$. que V.m ${ }^{\mathrm{d}}$. mandase enviar se les pagaria». AGS, G.A.; Leg. 406-221. Agustín de Ojeda a Felipe II, Rentería, 24 de octubre de 1594.

59 Aragón Ruano, A., El bosque guipuzcoano en la Edad Moderna: aprovechamiento, ordenamiento legal y conflictividad, Ob. Cit., p. 47.

${ }^{60}$ Goodman, D., El Poderío naval español. Historia de la Armada del siglo XVII, Ob. Cit., p. 369. Fernández Duro, C., A la mar madera. Libro Quinto de las Disquisiciones Náuticas, Ob. Cit., p. 344. Gómez Rivero, R., «La Superintendencia de construcción naval y fomento forestal en Guipúzcoa (1598-1611)» en A.H.D.E., n ${ }^{\circ}$ 56, Ob. Cit., p. 597.

${ }^{61}$ AGI, Indiferente, 1957, L.5, f.50v.

${ }^{62}$ Soria SeSÉ, L., «Bienes comunales en Navarra y las Provincias vascas (siglos XVIXVIII)» en Historia de la Propiedad en España. Bienes comunales, pasado y presente, Centro de Estudios Registrales, Madrid, 2002, p. 105.

${ }^{63}$ AGS, G.A., Leg. 490-106. Antonio de Urquiola a Felipe II. Lezo, 4 de octubre de 1597.

64 Tras el fracaso de la Armada Invencible se focalizó de alguna manera la construcción naval en el Puerto de Pasajes y rivera del Oria, convirtiéndose estos lugares indiscutiblemente en los principales centros de fabricación de bajeles y especializándose en producir naves de gran porte para las Armadas y Flotas Reales. De ahí la importancia de abastecer el astillero de maderas provenientes de los montes guipuzcoanos. Vid. OdRIO- 
ciertas poblaciones habían decidido no mantener ninguna comunicación con el exterior, tampoco para el acopio de materiales a los que obligaba el comisionado. Así las cosas, la villa de Rentería se negó a prestar ayuda en el acarreo y labra de la madera pero, a pesar de la epidemia, las necesidades navales seguían siendo inexcusables y se intentó no tener en cuenta las decisiones municipales de aislamiento, por lo que Urquiola tuvo que informar que, al no contar con el auxilio de operarios autóctonos, «se han traido los mas de los carpinteros que se hallan en esta Prouinçia y muchos dellos no han acostrumbrado en fabricas de nabes por no hauer otros. Y asi labraran la madera y tabla $\rangle^{65}$. Esta heterogeneidad en los carpinteros realmente no era infrecuente, pues su contratación llegaba a representar un amplio espectro de la sociedad, ya que durante el siglo XVI la Corona se valió para cubrir sus necesidades de todos los trabajadores que pudiesen serle útiles en el proceso de acopio y comercialización de la madera destinada a construcción naval ${ }^{66}$. Ante la llegada de tal cantidad de personal, la provincia intentó mediar en el conflicto entre Urquiola y la población comunicándole al nuevo Superintendente que «Ayer ymbiamos a Vm carta para que la Villa de Rentería aloje a los offiçiales que Vm ymbiase pagandoseles su alojamiento que tambien lo cumpliran. Suplicamos a Vm se tenga la consideracion que ymporta en que no se mescle gente de partes que aya sospecha de enfermedad para que no nos causen mayores daños ${ }^{67}$. Aún así, la resistencia del municipio a no colaborar se plasmó en su negativa de acoger a aquellos carpinteros contratados por el Superintendente -a pesar de haber sido ordenado por Urquiola y el Corregidor de Guipúzcoa, Diego Fernández de Arteaga-, persistiendo en su alegación de no querer contagiarse de la enfermedad, cerrando las puertas de la villa y poniendo guardas para no permitir la entrada de ninguna persona relacionada con la fábrica de bar$\cos ^{68}$. Desde la perspectiva de las necesidades navales no llegó a entenderse la resistencia del municipio, quejándose los constructores:

«acerca del grande Rigor que los de Renteria Hussan con nosotros. Es de manera que no nos dexan allegar a los Astilleros de allà a donde estàn y bienen algunos materiales de la fabrica. Y lo mismo hazen

zOLA OYARBide, L., «La construcción naval en Guipúzcoa. Siglos XVI-XVIII» en Itsas Memoria. Revista de Estudios Marítimos del País Vasco, nº 2, Ob. Cit., p.93.

${ }_{65}$ AGS; G.A., Leg. 490-106. Antonio de Urquiola a Felipe II. Lezo, 4 de octubre de 1597.

${ }^{66}$ Aragón Ruano, A., El bosque guipuzcoano en la Edad Moderna: aprovechamiento, ordenamiento legal y conflictividad, Ob. Cit., p. 120. Odriozola Oyarbide, L., «La construcción naval en Guipúzcoa. Siglos XVI-XVIII» en Itsas Memoria. Revista de Estudios Maritimos del País Vasco, n ${ }^{\circ}$ 2, Ob. Cit., p. 110.

${ }^{67}$ AGS, G.A., Leg. 490-127. La provincia de Guipúzcoa, a través de su escribano, Juan López de Tapia a Antonio de Urquiola, Tolosa, 5 de octubre de 1597.

68 AGS, G.A., Leg. 490-123. Antonio de Urquiola a Felipe II, Lezo, 9 de octubre de 1597. 
acerca de los bastimentos. A los principios nos cerraron las puertas sin ocasión. Y agora del todo punto por habersenos muerto en este lugar dos mugeres» ${ }^{69}$.

Similares desacuerdos se produjeron en el Señorío de Vizcaya tras la designación, a comienzos de 1598, del militar Agustín de Ojeda, como superintendente de Montes y Plantíos ${ }^{70}$. A los problemas originados por las instituciones territoriales para desempeñar sus funciones, el comisionado real también se vio obligado a afrontar la propagación de la peste en el Señorío, pero la situación fue solventada en los primeros meses de 1600, cuando acordó con los lugares del distrito plantar 53.034 ejemplares que habrían de sumarse a los 86.600 árboles que efectivamente llevaban plantados desde su acceso al cargo ${ }^{71}$. Sin embargo, la carencia económica para cumplir con las obligaciones legalmente establecidas era tan importante que el propio Ojeda se vio obligado a dirigirse al rey exponiendo que «no tengo credito ni de donde cobrar el sueldo que V.m ${ }^{\mathrm{d}}$. me tiene señalado, que me hallo en todo este exttremo de necessidad» ${ }^{72}$.

Por su parte, en Guipúzcoa la situación continuó siendo tensa, a pesar de que Urquiola falleció en verano de 1600. Le sucedió otro militar, Domingo de Idiáquez, el 21 de julio del siguiente año, quien se encontró con las mismas oposiciones, de las que trataremos pormenorizadamente en la segunda parte de este trabajo ${ }^{73}$. A pesar de intentar recorrer la costa y los parajes sujetos a su jurisdicción, ordenando plantíos, las protestas ante la Diputación y las Juntas provinciales de diversas villas, encabezadas por las del Valle de Oyarzun y San Sebastián, no se hicieron esperar ${ }^{74}$. Durante

${ }^{69}$ AGS, G.A., Leg. 490-395. Carta de Minarano de Valencegui a Felipe II, Lezo 30 de octubre de 1597.

70 AGS, G.A. 512-51. Agustín de Ojeda a Felipe II, Zorroza, 21 de febrero de 1598. AGS, G.A.; 565-59. Agustín de Ojeda a Felipe II, Zorroza, 2 de mayo de 1600. Acta del Regimiento General; 17 de octubre de 1598. De Sargarmínaga F. y de Areitio, D., El Gobierno y Régimen Foral del Señorío de Vizcaya, Vol. I, Ob. Cit., p. 126. Acta del Regimiento General, 22 de abril de 1598. De Sargarmínaga F. y de Areitio, D., El Gobierno y Régimen Foral del Señorio de Vizcaya, Vol. I, Ob. Cit., p. 165.

71 AGS, G.A., 565-60. Testimonio Agustín de Ojeda sobre de plantíos en el Señorío de Vizcaya, 1600.

72 AGS, G.A., Leg. 565-62; Agustín de Ojeda a Felipe III. Vizcaya, 21 de abril 1600.

73 AMN, Vargas Ponce, Ms. 75 / 031 (fols. 170-175) Copia fehaciente de Real Cédula encargando a Domingo de Idiáquez de la fábrica y arqueamientos de navíos de Guipúzcoa, así como de la conservación de los montes de dicha provincia, por muerte del general Antonio de Urquiola, Valladolid, 21 de julio de 1601. Gómez Rivero, R., «La Superintendencia de construcción naval y fomento forestal en Guipúzcoa (1598-1611)» en A.H.D.E., n ${ }^{\circ}$ 56, Ob. Cit., p. 606.

74 AMN, Vargas Ponce, Ms. 86 / 18 (fol. 38), San Sebastián 15 de septiembre de 1601 (copia del original del Archivo de Guipúzcoa). Gómez Rivero, R., «La Superintendencia de construcción naval y fomento forestal en Guipúzcoa (1598-1611)» en A.H.D.E., n ${ }^{\circ}$ 56, Ob. Cit., pp. 606, 607, 608 (cita A.G.G., Diputación de Tolosa, 15-IX-1601), 609 (en pie de página 78, cita A.G.G. Diputación de Tolosa, 18-IX-1601), 614-615 (cita A.D.S.S., 
casi diez años -exceptuando algún caso concreto de colaboración a partir de 1609- las Reales Cédulas y advertencias, esgrimidas por el Superintendente para que Guipúzcoa se plegase a sus mandatos ${ }^{75}$, se cruzaron con peticiones reiteradas de las Juntas Generales a la Corona para que éste cesase en su cargo. El órgano provincial, empleando en ocasiones, como luego analizaremos, el pase foral ${ }^{76}$, alegaba que la institución forestal creada por Felipe II era innecesaria, debido a que, si la Monarquía deseaba una plena colaboración, lo único que hacía falta era que los municipios, una vez hubiesen plantado su cuota asignada, entregasen sus testimonios directamente a la propia Junta guipuzcoana que, a su vez y de acuerdo con lo que entendían que eran sus propios derechos ${ }^{77}$, los remitiría al rey ${ }^{78}$. Este planteamiento se convertirá en recurrente y la situación en Guipúzcoa nunca fue del todo complaciente sobre las necesidades forestales de la Corona respecto de los montes de la Provincia. Un ejemplo concreto: en la primavera de 1607, Idiáquez visitó los concejos asignando determinadas cantidades de robles para los plantíos sin lograr un consenso con las villas. Incluso hubo quejas como las del barrio de Aguinaga, donde había ordenado plantar un tercio de los árboles que había repartido a Ursúbil. Sin embargo, Aguinaga no disponía de terrenos para poderlo llevar a cabo y lo puso en conocimiento de la Junta, «para que el dicho lugar no sea vexado ni padesca». La Provincia acordó escribir a Idiáquez que debía conformarse con lo que a ella se le había establecido por la Ordenanza provincial de 1548, que se plantaran 500 robles, y además, tal y como estaba señalado por la propia

J.G. de Elgóibar, de 13 de-IV-1606), 616 (pie de pág. nº 112, cita A.G.G., Sec. 2a , Neg. 13, Leg. 12). Aragón Ruano, A., El bosque guipuzcoano en la Edad Moderna: aprovechamiento, ordenamiento legal y conflictividad, Ob. Cit., p. 165.

75 Gómez Rivero, R., «La Superintendencia de construcción naval y fomento forestal en Guipúzcoa (1598-1611)» en A.H.D.E., nº 56, pp. 614-615 (cita A.D.S.S., J.G. de Elgóibar, de 13 de-IV-1606) y 616 (pie de pág. nº 112, cita A.G.G., Sec. 2a , Neg. 13, Leg. 12). Aragón Ruano, A., El bosque guipuzcoano en la Edad Moderna: aprovechamiento, ordenamiento legal y conflictividad, Ob. Cit., p. 165.

76 Gómez Rivero, R., «La Superintendencia de construcción naval y fomento forestal en Guipúzcoa (1598-1611)» en A.H.D.E., n ${ }^{\circ}$ 56, pp. 611-612 (cita A.G.G., Registro de la Junta Particular de Basarte; 3 de enero de 1602). De la Cruz Aguilar, E., La Destrucción de los Montes (Claves histórico-jurídicas), Servicio de Publicaciones de la Facultad de Derecho.- Universidad Complutense, Madrid, 1994, p. 81.

77 AGS, G.A., Leg. 726. La provincia de Guipúzcoa a Felipe III, 27 de noviembre de 1608. AGS, G.A., Leg. 726. La provincia de Guipúzcoa a Felipe III, 27 de noviembre de 1608. Ibídem. Documento sin fecha concreta, expediente relativo a los bosques del valle de Oyarzun, 1608-1609.

${ }^{78}$ Goodman, D., El Poderío naval español. Historia de la Armada del siglo XVII, Ob. Cit., p. 142-143. Gómez Rivero, R., «La Superintendencia de construcción naval y fomento forestal en Guipúzcoa (1598-1611)» en A.H.D.E., nº 56, p. 613 (cita a A.G.G., J.C. de 23-XI-1602 y A.G.G., J.C. de Tolosa; 8-V-1604). 
asamblea, se decidió que los alcaldes remitirían lo plantado en sus términos exclusivamente a ella, pasando por alto la jurisdicción superintendencial ${ }^{79}$. Simultáneamente a estos años últimos años del siglo XVI y primeros del XVII, a nivel internacional, hubo un período de tregua entre guerras provocado por el agotamiento de unos recursos y unas estructuras militares a las que les resultaba imposible dar más de sín $^{80}$. Así pues, esta situación de esquilmo generalizado, a la que se le añadieron desastres concatenados de las Armadas, vino a privar a la Corona de los recursos navales que necesitaba. Se requería un período de respiro a favor de las armas y finanzas españolas ${ }^{81}$, durante el que debía impulsarse el fomento forestal.

Aun así, en Guipúzcoa las reticencias continuaron y el coronel Idiáquez cesó a fines de marzo de 1611, al ser designado para la gobernación y alcaldía de Melilla. La reacción provincial no se hizo esperar y la Junta de Zumaya acordó decretar, el 23 de abril, poner un capítulo en la instrucción al agente de Corte para que hiciese diligencias encaminadas a que no se nombrase un nuevo superintendente. Sin embargo, a los pocos meses el rey nombró a un nuevo superintendente, Domingo de Echeverri ${ }^{82}$.

Tras el fin de la conocida como Pax Hispanica, la década de los años veinte del siglo XVII resultó frenética. La Monarquía Universal se vio inexorablemente empujada a la guerra aun faltándole fondos, medios y moral, y dependió en buena medida de los poderes locales ${ }^{83}$. A pesar de todo, en poco tiempo fueron varios los galeones construidos, quedando constancia de que «...se han fabricado muchos galeones, particularmente los que salieron a servir a Su magestad los años de $619-621$ - y 623 en las tres escuadras de las provincias de Cantabria - Guipúzcoa, Bizcaya y Quatro Villas de la Costa de la Mar, en la montañas de Burgos-... $\rangle^{84}$. Realmente, fue durante esta época

79 Gómez Rivero, R., «La Superintendencia de construcción naval y fomento forestal en Guipúzcoa (1598-1611)» en A.H.D.E., nº 56, p. 617. Sobre las Juntas, cita A.G.G. Caja 56, Leg. 1 y A.G.G., J.G. de Rentería; 8-V-1607.

80 Domínguez Nafría, J. C., El Real y Supremo Consejo de Guerra (siglos XVIXVIII), Ob. Cit., p. 103. Comellas, J. L., Historia de España moderna y contemporánea, Ed. Rialp, Madrid, 1967, pp. 197 y ss. Afirma que esta etapa de concordia «no puede ser considerada en sentido amplio como una paz, sino como una tregua».

${ }_{81}$ Alle, P. C., Felipe III y la Pax Hispanica, Ed. Alianza, Madrid, 2001, p. 322.

82 Gómez Rivero, R., «La Superintendencia de construcción naval y fomento forestal en Guipúzcoa (1598-1611)» en A.H.D.E., no 56, pp. 618-619 y 621. El nombramiento parece ser que se hizo con carácter provisional porque había estado previsto que el cargo fuese hereditario, correspondiéndole a Alonso de Idiáquez, hijo de Domingo de Idiáquez. Goodman sostiene que anteriormente había sido «Secretario Real». Vid. Goodman, D., El Poderío naval español. Historia de la Armada del siglo XVII, Ob. Cit., p. 369.

${ }^{83}$ Artaza Moreno, M. M ${ }^{\mathrm{a}}$., «Representación política y guerra naval en Galicia» en A.H.D.E., $\mathrm{n}^{\circ}$ 66, 1996, p. 449. Thompson, I. A. A., Guerra y decadencia: Gobierno y administración en la España de los Austrias, 1560-1620, Ed. Crítica, Barcelona, 1981, p. 122.

${ }^{84}$ Vicente Maroto, Ma . I., «La fábrica de navíos a principios del siglo XVII» (estudio preliminar y posterior transcripción del texto) en Diálogo entre un vizcaíno y un montañés 
cuando se produjo el máximo esfuerzo de todo el siglo XVII destinado a revitalizar y mejorar la construcción naval española ${ }^{85}$. El paradigma de este tipo de fomento naval en aquellos años había sido protagonizado por el Señorío de Vizcaya, que, como veremos en páginas posteriores, bajo ciertas condiciones pactadas con la Monarquía se comprometió, en 1617, a poner en marcha ocho navíos empleando mayoritariamente maderas de sus montes ${ }^{86}$. $\mathrm{Al}$ año siguiente, la provincia de Guipúzcoa, lugar en donde había un nuevo superintendente, Agustín de Ojeda ${ }^{87}$, hizo otro tanto acordando la fábrica de doce galeones ${ }^{88}$, a pesar de las resistencias de la villa de Hernani para que no se empleasen sus bosques ${ }^{89}$. Otras dificultades provinieron, en ocasiones, de que parte de las piezas requeridas debían tener formas infrecuentes en el normal crecimiento de los árboles. Las «curvas» alabeadas para los galeones eran tan extrañas en los árboles guipuzcoanos que en el contrato tuvo que incluirse una cláusula según la cual sólo podrían ser tomadas en montes vizcaínos con permiso del rey ${ }^{90}$.

A la explotación de los bosques hubo de añadírsele un nuevo factor de presión: el proyecto del conde-duque de Olivares, conocido como «Unión de Armas», mediante el que se pretendió unificar la Monarquía en el plano militar, planteándose en un memorial, de 13 de diciembre de 1625. Es conocido cómo el valido propuso de modo rotundo la unificación del Derecho sobre la base del de Castilla, lo que implicaba una ruptura con el hasta entonces respeto hacia la diversidad institucional hispánica ${ }^{91}$. Pero había más, puesto que, como acabamos de apuntar, en él se concebía un proyecto de defensa común, para las guerras que mantenía la Monarquía, basado en una alianza

sobre la fábrica de navíos, Ediciones Universidad de Salamanca, Salamanca, 1998, pp. 15 y 168. Valdez Buvnov, I., Naval Power and State Modernisation: Spanish Shipbuilding Policy in the Eighteenh Century, Ob. Cit., p. 25.

${ }_{85}$ Rahn Phillips, C., Seis galeones para el rey de España. La defensa imperial a principios del siglo XVII, Ob. Cit., p. 55. AMN, Vargas Ponce, Ms. 50 / 53 (fol. 82). Carta de Martín de Aróstegui a Domingo de Echevarri sobre la venta de unos navíos y la visita a montes y plantíos, Madrid, 5 de junio de 1623.

${ }^{86}$ Fernández Duro, C., A la mar madera. Libro Quinto de las Disquisiciones Náuticas, Ob. Cit., pp. 63-69.

87 Odriozola Oyarbide, L., «La construcción naval en Guipúzcoa. Siglos XVIXVIII» en Itsas Memoria. Revista de Estudios Maritimos del País Vasco, $\mathrm{n}^{\circ}$ 2, Ob. Cit., 111.

${ }^{88}$ Fernández Duro, C., A la mar madera. Libro Quinto de las Disquisiciones Náuticas, Ob. Cit., pp. 69-70.

${ }^{89}$ AMN, Vargas Ponce, Ms. 75 / 73 (fol. 281). Representación de la villa de Hernani para que el Corregidor de Guipúzcoa prohíba a los fabricantes de navíos de otras jurisdicciones cortar árboles de los montes de la jurisdicción de Hernani, necesarios para la construcción de dos galeones ofrecidos por esta Villa. Año 1618.

${ }^{0}$ Goodman, D., El Poderio naval español. Historia de la Armada del siglo XVII, Ob. Cit., p. 120.

${ }_{91}$ Ballester Rodríguez, M., La identidad española en la Edad Moderna (15561665). Discursos, símbolos y mitos, Ed. Tecnos, Madrid, 2010, p. 434. 
de todos los recursos destinados a la defensa militar y naval ${ }^{92}$. Su objetivo era racionalizar la gestión de los efectivos bélicos mediante una liga entre los distintos reinos ${ }^{93}$ :

«El remedio de todos los daños que pueden ofrecerse consiste sólo en que como leales vasallos nos unamos todos (...) juzgando por cierto e indubitadamente que cesarán y se rendirán los enemigos todos de SM en viendo que sus Reinos se hallan cada uno con las sustancias de todos los otros y que es un cuerpo mismo» ${ }^{94}$.

Además de las reticencias periféricas, este interés por reconstruir las flotas perdidas encontraba dificultades en algo que no aparecía como novedoso: la falta de pecunia con la que también Felipe IV llegaba al trono ${ }^{95}$.

A pesar de las carencias financieras y de la elaboración de un nuevo plan, todavía en Vizcaya abundaban robles idóneos para la fabricación de barcos ${ }^{96}$, pero aún así la situación se encontraba lejos de resultar idílica porque los planes y órdenes de la Superintendencia para perseverar en la construcción de nuevos efectivos navales chocaban con otros problemas, también de índole económica, esta vez representados por las factorías del hierro, que suponían una importante industria para la zona ${ }^{97}$. Respecto a Guipúzcoa y aún existiendo también ferrerías, según Goodman, la carencia de madera tampoco existía en la década de los años veinte y por tanto no fue un problema, a pesar de no haber encontrado datos que avalen el cumplimiento de la obligación legal de efectuar plantíos ${ }^{98}$. Sin embargo, en otras ocasiones sí se produjeron conatos que, aunque menos generalizados que al comienzo del siglo XVII, suponían casos de resistencia municipal, incluso violenta, a pesar de que desde principios del reinado de Felipe III el Consejo de Guerra mostró la intención de solucionar los conflictos de competencias que se producían con otras instituciones jurisdiccionales, especialmente los suscitados con la

${ }^{92}$ Elliot, J. H., España y su mundo (1500-1700), Ed. Alianza, Madrid, 1990, pp. 47 y 284. Domínguez Nafría, J. C., El Real y Supremo Consejo de Guerra (siglos XVI-XVIII), Ob. Cit., p. 121.

${ }_{93}$ Fontana, J. y Villares, R. (dir.), Historia de España. La crisis de la Monarquía (Vol. 4), Ed. Crítica / Marcial Pons, Barcelona, 2009, p. 101.

${ }^{94}$ Elliot, J. H., La rebelión de los catalanes (1598-1640), Siglo XXI de España Editores, Madrid, 1977; p. 183.

95 Lynch, J., Los Austrias, Ed. Crítica, Barcelona, 2000, pp. 418-419. Domínguez Ortiz, A., Política y Hacienda de Felipe IV, Ed. Pegaso, Madrid, 1983, pp. 12 y 13.

${ }_{96}$ Goodman, D., El Poderío naval español. Historia de la Armada del siglo XVII, Ob. Cit., p. 158.

${ }_{97}$ AGS; G.A., Leg. 887. Carta de Juan de Pinedo a Felipe IV, Bilbao, 10 enero de 1622. Goodman, D., El Poderío naval español. Historia de la Armada del siglo XVII, Ob. Cit., 139.

${ }_{98}$ AGS, G.A., Leg. 889. 30 de enero de 1623. Goodman, D., El Poderío naval español. Historia de la Armada del siglo XVII, Ob. Cit., p. 158. 
jurisdicción ordinaria ${ }^{99}$, y sobre los que trataremos más detenidamente en páginas posteriores.

Los intereses por fomentar los montes no se frenaron y a fines de la década de 1620 la actividad forestal siguió manteniendo un especial protagonismo en la cornisa cantábrica. Particularmente, fue muy activa la actividad de la Superintendencia en el Señorío de Vizcaya, donde otro superintendente, Martín de Vallecilla, visitó en 1629 los territorios de su jurisdicción. Pero esta inspección no estuvo tampoco exenta de problemas. Aunque desde la última visita, de 1626, gran parte de los lugares habían cumplido con sus obligaciones forestales, «en otras se a hallado algunas faltas, asi en el plantar como en cultivar mal lo plantado», lo que le llevó a imponer multas por un total de 30.000 reales. Entendía que las instituciones locales no colaboraban como se desearía. Cualquier asunto, por nimio que supuestamente pudiese parecer, servía para que desde los municipios se intentase hacer valer su jurisdicción sobre la del comisionado regio, ya fuese por conflictos directos con los representantes vecinales como por resistencias y faltas de colaboración para que se investigasen talas ilegales ${ }^{100}$, lo que también continuó durante la siguiente década ${ }^{101}$. Además, la situación no resultó fácil para aquel agente real porque, a los problemas derivados de los conflictos de jurisdicciones y las talas prohibidas, se le sumaba la obligación de cumplir con sus obligaciones legales sin disponer tampoco de fondos suficientes, lo que incluso le llevó a tener que suplicar, en 1631, a la Monarquía que se le abonasen los retrasos en sus pagos para poder continuar con su trabajo ${ }^{102}$.

A pesar de todos los inconvenientes, los comisionados forestales, por lo general, no cejaron en sus labores. Ahora bien, en los intentos desde las diversas Superintendencias por tener maderas preparadas para la construcción naval, no se había tenido en cuenta un factor fundamental que había sido y seguiría siendo una constante: se talaba a un ritmo mayor de lo que se regeneraba el monte y esto ocurría desde los tiempos de Cristóbal de Barros.

99 Domínguez Nafría, J. C., El Real y Supremo Consejo de Guerra (siglos XVI$X V I I I), O b . C i t .$, pp. 36 y 123. Afirma que en sus actuaciones la Corona pretendió con frecuencia conciliar los problemas suscitados por su política exterior con las instituciones jurídico-públicas de cada territorio. AGS, G.A., Leg. 910, Alonso de Idiáquez a Martín de Aróstegui, Lezo, 24 de noviembre de 1624.

100 AGS, G.A., Leg. 1070. «Certificación del Escriu . de la Visita de plantios del señorio de Vizcaya por donde consta como salio a ella el Superintendente de fabricas y plantios del. Y como el alcalde de Bilbao se escuso de firmar una orden y auto tocante a los dhos plantios». Testimonio del escribano Lucas de Curmano, Bilbao, 22 de diciembre de 1629.

${ }^{101}$ Ibídem. Pocos días después, desde Portugalete en 8 de enero de 1630. Goodman, D., El Poderío naval español. Historia de la Armada del siglo XVII, Ob. Cit., p. 135. AGS, G.A., Leg. 1111. Carta de 30 de junio de 1630. AGS, G.A., Leg. 3157. Relación sobre los montes de Aranzazu. 12 de septiembre de 1631. AGS, G.A.; Leg. 1111. Martín de Vallecilla a Felipe IV, Portugalete, 21 de octubre de 1634.

102 AGS, G.A., Leg. 3157. «Testimonio de la Visita gral de montes y plantios del Señorio de Vizcaya que hizo el Superintendente Don Martin de Vallecilla, el año de 1631». 
Asunto éste que, en aquel mismo año de 1631, fue comunicado por Idiáquez desde Guipúzcoa al rey ${ }^{103}$. La cuestión no debió ser menor, porque cuatro años más tarde nos consta cómo volvieron a reservarse maderas provenientes de los montes de Navarra para paliar los efectos de la deforestación en aquella provincia vasca ${ }^{104}$.

Pero, a pesar de todas las actividades forestales y navales, la derrota de la batalla de las Dunas supuso un duro revés en 1639. A principios de ese año se había intentado trabajar a destajo en el cantábrico para la botadura de nuevos galeones y también hubo intentos por poner al día las deudas atrasadas con los más importantes asentistas ${ }^{105}$, contratistas privados al servicio de la Corona. Pero, aun con esos esfuerzos, desde entonces la Armada del Mar Océano decayó irreparablemente y no fue posible levantarla por el motivo de siempre: la falta de fondos. Los precios volvieron a subir entre 1641-1642 como resultado de otro importante crecimiento del vellón, consecuencia de los gastos de guerra ${ }^{106}$. Aún así la Monarquía continuó con su intención de construir más galeones ${ }^{107}$. Ello significó una importante actividad en los bosques próximos al litoral vizcaíno y hubo oposiciones puntuales a nivel municipal. No obstante, las noticias nos proporcionan la información suficiente como para concluir que Vallecilla perseveró en cumplir con sus tareas y nos consta que a fines de 1642 visitó los montes del Señorío ${ }^{108}$, llegando a ser moderadamente optimista sobre las previsiones de futuras producciones madereras ${ }^{109}$, y ello a pesar de detectar infracciones, que fueron castigadas, así como oposiciones municipales y de las Juntas vizcaínas ${ }^{110}$. Sobre estas últimas criticó diversas medidas que habían adoptado, ya que entendía que éstas sólo podían a su vez funcionar mediante una «facultad delegada» de la Corona, y en este asunto se estaban extralimitando «porque dividir ni rrepartir montes concejiles ni exidos

${ }_{103}$ AGS, G.A., Leg. 3157. Carta de Idiáquez a Felipe IV, 30 de enero de 1631.

104 AMN, Vargas Ponce, Ms. 046/56 (fols. 83-84). Real Despacho al marqués de Valparaíso, virrey y capitán general del Reino de Navarra y capitán general de la provincia de Guipúzcoa, prohibiendo que se corten los montes que quería reservarse Juan de Echeverri para construir un galeón a la vuelta de su jornada de Brasil. 5 de diciembre de 1634 . Ibídem, Ms. 046/57 (fols. 85-85). Real despacho a Alonso de Idiáquez, superintendente de fábricas y plantíos de la provincia de Guipúzcoa, prohibiendo que se corten los montes que quería reservarse Juan de Echeverri en Navarra para la construcción de un galeón. 5 de diciembre de 1634 .

${ }^{105}$ Alcalá-Zamora y QueIPo de Llano, J., España, Flandes y el Mar del Norte; Centro de Estudios Políticos y Constitucionales, Madrid, 2001, p. 413.

${ }^{106}$ Lynch, J., Los Austrias, Ob. Cit., p. 419.

107 Domínguez Ortiz, A., «La España del Conde Duque de Olivares» en La España del Conde Duque de Olivares, Universidad de Valladolid, Valladolid, 1990, p. 35.

108 AGS, G.A., Leg. 3221. Testimonio del escribano Martín de Arauco Uracandi sobre la visita del Superintendente Martín de Vallecilla, Bilbao, 8 de diciembre de 1642.

109 Ibídem.

110 AGS, G.A., Leg. 3221. Martín de Vallecilla a Felipe IV. Portugalete, 28 de diciembre de 1642 . 
comunes no lo pueden hazer sin la facultad Real de V. Mag $\left.{ }^{\mathrm{d}}.\right\rangle^{111}$. Al fin y al cabo, él era plenamente consciente que su principal obligación chocaba con los intereses del Señorío ya que, desde su nombramiento en 1626, ésta versaba en impulsar la plantación de árboles y prevenir talas que necesitaban los habitantes de la zona, de aún quienes requería su ayuda ${ }^{112}$. Precisamente por esa necesidad que tenía de colaboración por parte de las autoridades locales, su queja fue enorme cuando tuvo conocimiento de importantes daños causados por la búsqueda de combustible para las ferrerías de Bermeo, lo que le hizo chocar con los propietarios de aquellas industrias, titulares a su vez de la jurisdicción municipal ordinaria ${ }^{113}$.

Sin embargo, en los siguientes años de la década de 1640 la actividad naval decayó, lo que irremisiblemente debió arrastrar en su declive a los asuntos forestales sujetos al Real Servicio. Aún así, tuvieron lugar cambios en la provincia de Guipúzcoa. En 1645 accedió a la Superintendencia Miguel de Necolalde, quien abandonó el cargo a los dos años, lo que hizo que se nombrase a su primogénito, Luis de Necolalde. Se le ordenó residir en la provincia, debiendo visitar sus bosques dos veces al año en los períodos que estimase convenientes. Al igual que sus antecesores, su jurisdicción abarcaba todos aquellos montes comprendidos a dos leguas de la costa de la mar o ríos navegables. Nuevamente, en su título de nombramiento, la Corona requería el auxilio de las instituciones locales y encargaba al superintendente que se hiciese cargo del reparto de plantíos entre los vecinos. Éste debería tener una cuota de ejemplares a determinar en función de la cantidad y calidad de las tierras que, como venía siendo usual, debían preservarse de la acción de los ganados. Se le obligó a elaborar una relación anual sobre los repartos y testimonios de cada lugar, que serían entregados «al mi veedor y contador que es o fuere de la jente de guerra que me sirue en las Villas de Fuenterrauia y san seuastian para que tengan Raçon dello en sus libros». Igualmente, el monarca le otorgó la ya asentada facultad para sancionar y «ejecutar las penas declaradas en los que fueren remisos y descuidados en el plantio de los arboles que les rrepartieredes y para repartirlas por terçias partes $\rangle^{114}$.

No obstante y a pesar de todo, la existencia de disposiciones forestales en diferentes territorios de la Monarquía no tuvo una efectiva repercusión en un incremento de flotas que se deseaba, pero no se alcanzaba. Un embajador

111 Ibídem.

112 AGS, G.A.; Leg. 3221. Carta de Martín de Vallecilla a Felipe IV, Bermeo, 11 de noviembre de 1643 .

113 Ibídem.

114 AMN, Vargas Ponce, Ms., 52 / 77 (fols. 124-127). Cédula de Retiro al veedor general Miguel de Necolalde, superintendente de fábricas y plantíos de montes de Guipúzcoa, y nombramiento para el mismo cargo a favor de su hijo Luis de Necolalde, Madrid, 14 de septiembre de 1647. 
veneciano resumía el estado en el que se encontraba la Armada española en el último tercio del siglo XVII:

«En cuanto á las fuerzas navales, ya dije que en aquellas aguas (del Mediterráneo) no hay más que seis galeras de mala construcción. Las de Nápoles, Sicilia y Cerdeña, y las de la escuadra del duque de Cursi, no son más que dieciocho entre todas. Seis se perdieron, unas idas á pique, otras tristemente apresadas por los corsarios durante los tres años de mi permanencia en España, no habiéndose vuelto á pensar en reemplazarlas. Como se encuentran armadas y provistas, sábelo Dios, y también lo saben VV.EE., desde que yo, humildemente, lo participé al resolver no visitar al Rey por Levante, á causa de la increíble inutilidad de aquellas. Felipe IV ha disminuido tanto la escuadra de Nápoles, que lo que queda puede ser contado por quien nunca haya aprendido la numeración (...). De modo que, en cuanto á naves, sábese ya cómo se encuentra actualmente el rey de España (...). Los galeones armados este año para las Indias son casi todos holandeses (...) De estas fuerzas marítimas no diré más sino que los españoles, ó no conocen su importancia, y por esto no las estiman, ó conociendo su importancia no se esfuerzan en remediar el daño. Esta nación poseyó tantas tierras porque no desatendía sus fuerzas de mar; y en este caso, siendo también esta ley lo mismo para los contrarios, excuso añadir más $\rangle^{115}$.

En 1667 el Señorío de Vizcaya representó que la construcción de barcos para la Corona estaba abandonada y que necesitaba ser estimulada por el gobierno ${ }^{116}$. La crisis no sólo afectaba a la institución superintendencial, sino que también era operativa. Por esta razón y como veremos más detenidamente, fue promulgada para la provincia de Guipúzcoa otra norma forestal, de 11 de abril de 1670, titulada «Conservación de los Montes, so penas graves» ${ }^{117}$, en la que se reconocía la fabricación de barcos como una de las causas del agotamiento de los bosques, pero a su vez intentaba conciliarla con el fomento silvícola al reconocer la necesidad perentoria

115 Fernández Duro, C., Armada Española. Desde la unión de los Reinos de Castilla y Aragón, Vol. V, Museo Naval, Madrid, 1972-1973, p. 88. Cita Relaciones de los Embajadores de Venecia, Zeno, p. 286.

116 Fernández Duro, C., A la mar madera. Libro Quinto de las Disquisiciones Náuticas, Ob. Cit., p. 99.

117 Recogida en la compilación efectuada por Soraluce, N., Fueros de Guipúzcoa. Títulos adicionales y consideraciones, reglamentos, sumario histórico, etc., Imprenta del Banco Industrial, Madrid, y Mercantil. Edición facsímil de Analecta Ediciones, Pamplona, 1866. Esta disposición aparece numerada en el Título XXXVIII, Cap. V. Dentro del mismo Título se ubican otras normas forestales bajo los enunciados de "Castigo á los Incendiarios de los Aulagales ó Argomales» (Cap. VI), «Nombramientos de Guarda-Montes, y Penas sobre cortes de ramas de los árboles» (Cap. VII), « Plantaciones de Viveros, destinando el decimo de los ingresos de los pueblos, y sobre corte de arboles» (Cap. VIII). 
que existía para seguir construyendo unidades navales. Para ello, no sólo adoptaba medidas forestales, sino que establecía sanciones, además de requerirse nuevamente la colaboración de las autoridades locales. Sin embargo, su efectividad debió ser escasa, pues cuatro años después, la regente tuvo que volver a reiterar las disposiciones normativas que prohibían la explotación ilícita de los bosques guipuzcoanos ${ }^{118}$. En esta coyuntura las Superintendencias de Montes y Plantíos seguían perviviendo pero, paulatinamente, fueron perdiendo su sentido porque como hemos apuntado, entre otros factores, la actividad constructora llegó a ser muy escasa durante el reinado de Carlos II.

En otro orden de cosas, en 1676, un nuevo Martín de Vallecilla, hijo del anterior, fue designado para estar al frente del cargo en el Señorío de Vizcaya $^{119}$. Pero, en efecto, como reflejo de esa decadencia operativa a la que antes nos referíamos, la continuidad de nombramientos al frente de la Superintendencia no tuvo correlación con las unidades navales que se fabricaron. Por ejemplo, la escasa actividad constructiva debió ser tan acuciante que al superintendente de Guipúzcoa, Luis de Necolalde ${ }^{120}$, se le emplazó a remitir relación detallada de las fragatas que había en los puertos de la Provincia, con referencia a sus portes, calidades, precios, a quienes pertenecían y si sus dueños estaban dispuestos a venderlas ${ }^{121}$.

En el contexto internacional, durante los últimos años de la dinastía austriaca la fortaleza naval había menguado de manera ostensible en todos los ámbitos, también en el de la fabricación de navíos, mientras que, coetáneamente, al otro lado de las fronteras se vivía una etapa de entusiasmo respecto de las ideas y medidas jurídicas proclives al reforzamiento del dominio de los mares ${ }^{122}$. Este escenario era el resultado lógico de los graves errores de gestión y organización hispánicos que continuadamente existieron desde las últimas décadas del siglo XVI ${ }^{123}$. Dicha tendencia acrecentó la grieta que ale-

118 AMN, Asuntos diversos de Marina, Ms., 580 (fol. 23 r.-23 v.). Orden de la Reina Gobernadora, Madrid, 8 de abril de 1674.

119 AGS, G y M, Libro de registro 340. Pp. 18 r.-19 r. 28 de febrero de 1676. Sin embargo, en su nombramiento no hemos encontrado referencia alguna a de sus obligaciones, sino una única mención a su sueldo y el reconocimiento de que sustituía a su padre como superintendente en Vizcaya.

120 AGI, Indiferente General, 2740. Luis de Necolalde aparece como «Superintendente de fabricas y Plantios en la Prouincia de Guipuzcoa» en un documento sobre medidas de naves fechado en 15 de agosto de 1674.

121 AGI, Indiferente 441, L.28, f.11v. Real Disposición, 4 de enero de 1676.

122 De Diego García, E., «Estructuras y Organización Naval: Departamentos y Arsenales Peninsulares», en XXVI Jornadas de Historia Maritima y «Arsenales y Construcción naval en el siglo de la Ilustración» en Cuadernos Monográficos del Instituto de Historia y Cultura Naval, no 41, Madrid, 2002, pp. 15-17

${ }^{123}$ Quintero González, J., La Carraca. El primer arsenal ilustrado español (17171776), Ministerio de Defensa.- Instituto de Historia y Cultura Naval, Madrid, 2004, p. 25. Goodman, D., El Poderío naval español. Historia de la Armada del siglo XVII, Ob. Cit., p. 52. 
jaba a la Monarquía Católica de las grandes potencias marítimas de entonces, para quienes una España decadente no representaba un peligro de entidad. Aún así, el cambio de dinastía no afectó a la existencia, pero sí a sus competencias e intensidad, de la institución de las Superintendencias forestales en el cantábrico. Éstas continuaron perviviendo como a finales del siglo anterior, es decir, languideciendo poco a poco y feneciendo a golpe de normas que fagocitaban sus atribuciones sin siguiera nombrarlas.

Sabemos que poco después de la muerte de Carlos II, aún en el año 1700, fue otorgada una Real Cédula al superintendente de bajeles, montes y plantíos de Guipúzcoa Francisco Necolalde y Zabaleta, encargándole la fábrica y apresto de dos galeones para las naves capitana y almiranta de la flota de Nueva España. En ella se le reconoció la «jurisdicción civil y criminal» que precisase para llevar a cabo su cometido ${ }^{124}$. Sin embargo, a este ministro no le quedó otra que responder acerca de las dificultades que tenía para desarrollar el encargo como consecuencia de «la suma falta de medios» que padecía, pues incluso se habían efectuado cortas cuyas maderas quedaron en los montes de Santoña sin poder utilizarse. Finalmente, el Consejo de Guerra propuso que un oficial del mismo se encargase de su entrega $^{125}$. Pocos años más tarde, en 1704, la Corona le agradeció todos los esfuerzos que realizó para poner en funcionamiento las naves, en plena Guerra de Sucesión, que fueron construidas en el puerto de Pasajes ${ }^{126}$. Éstos serían los últimos galeones fabricados de acuerdo con los sistemas de construcción de los Austrias ${ }^{127}$.

El declive de la institución silvícola continuó, lento pero imparable. Para impulsar la defensa naval, por Real Orden, de 28 de enero de 1717, se nombró a José Patiño y Rosales como Intendente General de Marina ${ }^{128}$, quien se erigió en el artífice de la adopción de nuevas medidas y la creación de novedosos cargos forestales que terminarían sustrayendo paulatinamente las competencias de los ya vetustos superintendentes de Montes.

124 AMN, Vargas Ponce, Ms., 75 bis / 39 (fols. 184-186).

125 AGI, Indiferente General, 2514. Libro 5. (folio 11 r, 16 v- 17 r). Real Cédula, Madrid, 28 de Junio de 1702.

126 AGI, Indiferente General, 2514. Libro 4. Real Cédula, Plasencia, 31 de marzo de 1704. Aparece como « $\mathrm{D}^{\mathrm{n}}$. fran ${ }^{\mathrm{co}}$. Necolalde Zaualeta $\mathrm{Cau}^{\mathrm{ro}}$. del orden de $\mathrm{S}^{\mathrm{n}}$ Tiago del tribunal de Quentas de mi Cons ${ }^{\circ}$. De Hazda. y Superintendente de fabricas y Plantios de la Prou ${ }^{\mathrm{a}}$. de Guipuzcoa».

127 Apestegui, C., «La arquitectura naval entre 1660 y 1754. Aproximación a los aspectos tecnológicos y su reflejo en la construcción en Guipúzcoa», en Itsas Memoria. Revista de Estudios Marítimos del País Vasco, núm. 2, Ob. Cit., p. 241. Afirma que las últimas unidades construidas en aquel siglo bajo aquel sistema fueron la Capitana y Almiranta de la Flota de Nueva España, construidas en los astilleros de Mápil por Francisco Necolalde Zabaleta entre 1700 y 1704.

${ }_{128}$ AGI, Contratación 5786, L. 2. Orduña Rebollo, E., Intendentes e Intendencias, Tres Américas, Madrid, 1997, p. 58. 
Desde entonces, las noticias que han llegado hasta nosotros son fragmentarias. Sabemos que en Guipúzcoa, Francisco de Necolalde, siguió al frente de la Superintendencia hasta 1718. Tras él ocupó el cargo Martín de Olózaga y Espilla ${ }^{129}$. Desconocemos la duración de éste en la institución. Según Aragón Ruano, el último superintendente de Montes y Plantíos de la provincia fue el Marqués de Rocaverde, al menos desde $1736^{130}$. Sin embargo, en virtud de la documentación consultada, sabemos que Olózaga jugará un importante papel en la elaboración de normas para aquella provincia en 1738 , aún en calidad de superintendente de Montes ${ }^{131}$.

Así pues, parece claro es que las Superintendencias de Montes y Plantíos continuaron perviviendo, con mayor o menor intensidad, durante las primeras décadas del siglo XVIII. Coexistieron con nuevos ministros de Marina, de cuño borbónico, como reflejo de un proceso de transición, a pesar de que su ámbito competencial fue siendo abarcado paulatinamente por estas nuevas figuras nacidas de las reformas hechas desde la Secretaría de Marina ${ }^{132}$. Desde entonces los ya vetustos comisionados forestales tuvieron sus días contados siendo su golpe de gracia la promulgación de una norma general sobre la materia, la Real Ordenanza de Montes y Plantíos, de 31 de enero de $1748^{133}$, destinada a abastecer los novedosos arsenales que la nueva dinastía había construido gradualmente, ninguno en territorio vasco, sino en Cádiz, Cartagena y Ferrol.

\section{ANÁLISIS SISTEMÁTICO: LA DIVERSIDAD DE LEGISLA- CIONES E INSTITUCIONES FORESTALES EN LOS TERRITO- RIOS VASCOS}

Según Bermejo Cabrero mediante el sistema de Superintendencias se trató de dotar a la organización política de la Monarquía «de mecanismos más flexibles y especializados de los existentes hasta entonces, basados fundamentalmente en la presencia de un rígido, pesado y tradicional sistema

129 Aragón Ruano, A., El bosque guipuzcoano en la Edad Moderna: aprovechamiento, ordenamiento legal y conflictividad, Ob. Cit., p. 47. Cita copia de la Real Cédula por la que se nombraba a Martín de Olózaga y Espilla superintendente de los plantíos de los montes de Guipúzcoa, con el pase foral de ésta (20 de mayo de 1718, El Pardo) (A.G.G.G.A.O, JD IM 1/17/19; A.H.N. Consejos 105859).

${ }^{130}$ Ibídem.

131 AGS, Marina; leg. 577.

${ }^{132}$ La expresión proceso de transición es empleada por ArAgón RuANo, A., El bosque guipuzcoano en la Edad Moderna: aprovechamiento, ordenamiento legal y conflictividad, Ob. Cit., p. 48.

133 «Ordenanza, que Su Magestad (Dios le Guarde) manda observar para la cria, conservacion, plantios y Corta de los Montes, con especialidad de los que estàn inmediatos à la Mar, y Rios Navegables. Metodo, y reglas que en esta materia deben seguir los intendentes de Marina, establecidos en los tres Departamentos de Cadiz, Ferrol y Cartagena». Ejemplar empleado del AMN F006-41. También recogido en Novísima Recopilación, Lib. VII, Tít. XXIV, Ley XXII. 
polisinodal», formado por los Consejos y Juntas que actuaban en la administración central ${ }^{134}$.

El mundo jurisdiccional en el que se encontraron inmersas las Superintendencias de Montes y Plantíos presentaba un modo de organizar y gestionar el poder que provenía de la Baja Edad Media y mostraba escasas diferencias en todos los espacios políticos europeos ${ }^{135}$. Ha de tenerse en cuenta que los superintendentes forestales, investidos formalmente de competencias desde 1574, disponían de una jurisdicción propia proyectada sobre todos los asuntos silvícolas suscitados en áreas previamente asignadas. Sin embargo, no eran éstos los únicos agentes que gozaban de sus propios ámbitos de jurisdicción en los territorios cantábricos comprendidos dentro de las dos leguas próximas a la mar o ríos navegables: la diversidad y la pluralidad de la personalidad orgánica con la que se concebía cada comunidad, y que intentaba conciliarse ${ }^{136}$, era palpable en la organización jurídico-administrativa de las demarcaciones hispánicas modernas, lo que hacía que el panorama jurisdiccional fuese verdaderamente complejo, y el área en donde se desarrolló la labor de las Superintendencias de Montes, la cantábrica, no fue una excepción $^{137}$.

Por otro lado, los juristas consolidaron la idea de que el príncipe era la exclusiva fuente y origen de toda jurisdicción. Pero no ha de confundirse esta idea con una centralización efectiva del poder, ni con una, entonces impensable, unificación del espacio político. El príncipe se sitúa como garante máximo del equilibrio entre los diversos cuerpos, manteniendo a cada uno en el goce de sus respectivos derechos ${ }^{138}$. Estos intentos por armonizar las diferentes entidades se mostraron ocasionalmente en los asuntos de fomento forestal, en los que el monarca mostró una buena disposición para que se ejecutasen medidas a favor del Real Servicio pero sin generar perjuicios a los municipios. Sabemos que el 5 de enero de 1599 el rey emitió una Real Cédula, fechada en Madrid en la que exponía cómo el superintendente en Guipúzcoa había comunicado la intención de la Provincia por hacerse con la ejecución de los plantíos ${ }^{139}$. Estando así las cosas, Felipe III expresó en ella su intención de que aquel comisionado re-

134 Bermejo Cabrero, J. L., «Juntas y superintendencias de minas (siglos XVIIXVIII)» en A.H.D.E., Madrid, 2001, p. 111.

135 AgÜERo, A., «Las categorías básicas de la cultura jurisdiccional» en De justicia de jueces a justicia de leyes: hacia la España de 1870, Cuadernos de Derecho Judicial Madrid. Consejo general del Poder Judicial, Madrid, 2007, p. 24.

${ }^{136}$ Ibídem, p. 27.

137 Clavero, B., «Anatomía de España. Derechos hispanos y Derecho español entre códigos y fueros» en Hispania. Entre Derechos propios y Derechos nacionales, Giuffrè Editore, Milán, 1990, pp. 53 y 56.

138 AgÜERo, A., «Las categorías básicas de la cultura jurisdiccional» en De justicia de jueces a justicia de leyes: hacia la España de 1870, Ob. Cit., p. 38.

139 AMN, Vargas Ponce, Ms., Tomo. III, Doc. 31, Fol. 167 r ro.- 168 ro. Copia autentificada del original en A.G.G., Sec. 2a , Neg. 17, Leg. 11. 
gio, Antonio de Urquiola, dialogase con la «Junta Procuradores Caballeros hijos dalgo de la mui noble y mui leal Prouincia de Guipuzcoa» sobre el modo de llevarlos a cabo:

«El General Antonio de Urquiola me ha advertido q ${ }^{\mathrm{e}}$. hauiendo Platicado en la Junta que essa Prouincia ha hecho postreram ${ }^{\text {te }}$. cerca de la Orden que he mandado dar quanto à lo de los Plantios os haueis dado à entender que por algunas consideraciones y para que mejor se haga mi Seruicio deseais encargaros de la execucion de las Ordenanzas que cerca desto he mandado dar, y por que hà parescido que tomandolo por vuestra quenta y cargo la dareis dello como de todas las demas cosas de mi Seruicio hè mandado escribir al dicho Urquiola que platique con vos de la forma que esto se hade hacer para que teniendolo entendido pues ya lo esta quanto conuiene que en el cumplim $^{\text {to }}$. de las ordenes que cerca desto he mandado dar no haya falta lo dispongais de manera que se haga lo que conuiene y sea con la mayor breuedad y menos pesadumbre de los vecinos» ${ }^{140}$.

Así las cosas, jurisdicción real y otras formaban regímenes coincidentes, yuxtapuestos o concurrentes hasta dentro de una misma zona. De ahí que surgieran, con cierta asiduidad, numerosos conflictos y choques de naturaleza competencial sobre cualquiera de las actividades propias de unos territorios e instituciones que nunca vivieron de espaldas al monte ${ }^{141}$, pues, como a continuación veremos, la vida grupal de estas comunidades rurales estaba basada fundamentalmente en los bienes comunes que pudiesen disponer ${ }^{142}$.

Más específicamente, en el caso de los territorios vascos, como órganos vertebradores de cada una de sus provincias o Señorío, las Juntas Generales habían encontrado su génesis en la constitución de las diversas comunidades locales que tenían intereses y preocupaciones comunes y necesitaban de una mínima organización. Aquéllas eran el instrumento empleado para el debate y la adopción de decisiones ${ }^{143}$.

Estas instituciones representaban los intereses de sus territorios, erigiéndose como interlocutores válidos entre la Monarquía y éstos. Aunque tam-

140 AMN, Vargas Ponce, Ms., 75 / 031 (fols. 167-168). Real Cédula dirigida a Guipúzcoa para que trate con Antonio de Urquiola de la forma de ejecutar las ordenanzas sobre plantíos, Madrid, 5 de enero de 1599.

${ }^{141}$ Rodríguez Fernández, A., Alcaldes y regidores. Administración territorial y gobierno municipal en Cantabria durante la Edad Moderna, Institución Cultural de Cantabria \& Ediciones Librería Estudio, Santander, 1986, pp. 7, 8 y 25. Afirma literalmente que en la cornisa cantábrica el mapa regional era un «abigarrado mosaico de múltiples jurisdicciones».

${ }^{142}$ Mannori, L., y Sordi, B., Storia del diritto amministrativo, Roma-Bari, Editori Laterza, Roma, 2001, p. 25.

143 Ayerbe Iríbar, Ma . R., «Las Juntas Generales vascas. En defensa de la foralidad y de los derechos históricos» en Ivs Fvgit, n 15, Ob. Cit., p. 304. 
bién se encargaban de los problemas supramunicipales ${ }^{144}$, los apoderados que acudían a las Juntas eran antes conscientes de actuar en favor de las necesidades de sus respectivas corporaciones (villas, ciudades, anteiglesias, etc), que de portar una mera representación provincial ${ }^{145}$. Ahora bien, resulta preciso puntualizar que esta idea no significaba una lógica entre centro y periferia sin más. Recogiendo la idea de Portillo Valdés:

«...ni las provincias se sentían periferia ni la monarquía acertaba muy bien a adivinar su centro. La lógica es aquí otra en la que la provincia se presenta como uno de los agregados corporativos que, sin mezclarse (...) constituían la monarquía católica...» ${ }^{146}$.

La denominación de Juntas se debía a la concentración de los procuradores junteros nombrados por las entidades locales -villas, alcaldías o valles- que duraba varios días ${ }^{147}$. Por su parte, el calificativo de «Generales» era consecuencia de tratarse de unas agrupaciones abiertas a cualquier clase de asuntos, por lo que los procuradores podían presentar sus propios temas a la consideración de las Juntas ${ }^{148}$. Por debajo de las Juntas se encontraban las Diputaciones, siendo delegaciones de aquéllas durante el ínterin en que no estuviesen reunidas.

Dado que la jurisdicción de las superintendencias de montes sólo abarcaban las zonas más próximas al litoral, salvo determinadas corrientes fluviales que se adentraban en el territorio, no se tratará en estas páginas de las Juntas alavesas, sino únicamente de las vizcaínas y guipuzcoanas. En ellas, además de reunirse los procuradores como representantes de las anteiglesias, villas, alcaldías, valles y hermandades, se encontraba el corregidor, quien iniciaba sus sesiones. Al ser éste representante y velador de los derechos del Rey, a través de él recibían tanto el Señorío como la Provincia una parte muy importante de las disposiciones reales. También participaba en los debates cuando el tema lo requería, garantizaba el orden en las sesiones, denunciaba descuidos en las obligaciones «de buen gobierno», supervisaba las cuentas y levantaba las sesiones. Pero en las Juntas también se le recriminaba o supli-

144 Ibídem, pp. 304-305.

145 Portillo Valdés, J. M., Monarquía y Gobierno Provincial. Poder y Constitución en las provincias vascas (1760-1808), Centro de Estudios Constitucionales, Madrid, 1991, pp. 220-221.

146 Ibídem, p. 218.

147 Como ha demostrado MuÑoz de Bustillo, esta composición no era exclusivamente vasca, ya que en Asturias se reunían Juntas y Diputaciones de características muy similares, especialmente con las guipuzcoanas, dado el carácter realengo de las tierras en ambas regiones. Vid. MuÑOZ DE Bustillo, C., «Encuentros y desencuentros en la Historia: los territorios del Norte Peninsular en la coyuntura del Setecientos» en Revista del Departamento de Historia Contemporánea de Universidad del País Vasco, $\mathrm{n}^{\mathrm{o}}$ 12, Bilbao, 1995, p. 146.

${ }_{148}$ Ayerbe Iríbar, Ma . R., «Las Juntas Generales vascas. En defensa de la foralidad y de los derechos históricos» en Ivs Fvgit, nº 15, Ob. Cit., p. 305. 
caba, según el caso, determinadas actuaciones en aras a la mejor determinación de los negocios y bien de las comunidades ${ }^{149}$. Según Soria SEsÉ, L., «ese control mutuo daba lugar a un respeto también mutuo, base de la estabilidad del gobierno y de la efectividad administrativa; estabilidad sólo rota cuando alguna de las partes extralimitaba sus funciones $\rangle^{150}$.

Los diversos espacios jurisdiccionales compuestos por comunidades, corporaciones y personas, que se aglutinaban e interactuaban dentro de las provincias, poseían unos límites muy difuminados y nada precisos. Junto a aquéllos debieron moverse los superintendentes, dentro de un constante proceso de definición jurisprudencial mediante el que se intentaron definir los espacios de poder de cada una de las entidades que concurrían ${ }^{151}$, entre las que se encontraban las que se desenvolvían en el ámbito forestal. Dicho ámbito tuvo una especial incidencia en las provincias marítimas vascas por cuanto la construcción naval fue uno de los puntales de su economía, impulsada, como sabemos por la política exterior desarrollada por los Austrias, realizando en determinados momentos históricos una actividad febril que tomó los bosques más accesibles para su explotación ${ }^{152}$.

\subsection{Vizcaya}

De los dos territorios vascos que trataremos en esta ocasión, el que presentaba una mayor diversidad corporativa era el Señorío de Vizcaya ${ }^{153}$, presentando como es sabido cuatro agregados institucionales: la Tierra Llana, el Duranguesado, las Encartaciones y las Villas ${ }^{154}$, amén de las Juntas Generales, en la cúspide de la representatividad del Señorío ${ }^{155}$. Además, desde me-

149 Sobre la defensa de la Provincia en favor de los intereses municipales frente a los de los corregidores, vid. Soria Sesé, L., Derecho municipal guipuzcoano. Categorías normativas y comportamientos sociales, Administración de la Comunidad Autónoma de Euskadi, Bilbao, 1992, p. 63.

${ }^{150}$ Ibídem, pp. 304-306. Sobre el equilibrio a nivel provincial entre ambas esferas de poder, vid. Portillo Valdés, J. M., Monarquía y Gobierno Provincial. Poder y Constitución en las provincias vascas (1760-1808), Ob. Cit., p. 379.

151 Ibídem, p. 379.

152 BAZÁn DíAz, I., «De los tiempos oscuros al esplendor foral (siglos V al XVI)» en De Túbal a Aitor. Historia de Vasconia, La Esfera de los Libros, Madrid, 2002, p. 250.

153 Valdés, J. M., Monarquía y Gobierno Provincial. Poder y Constitución en las provincias vascas (1760-1808), Ob. Cit., p. 261-262.

${ }^{154}$ Enríquez Fernández, J., y Sesmero Cutanda, E., «Representación social y tensiones políticos en las asambleas representativas del Señorío de Bizkaia (c. 1550 - c. 1630)» en (Coord. AA.VV.), Actes del 53 è Congrés de la Comissió Internacional per a l'Estudi de la Història de les Institucions Representatives i Parlamentàries, pp. 171-173. BAZÁN DíAz, I., «De los tiempos oscuros al esplendor foral (siglos V al XVI)» en De Túbal a Aitor. Historia de Vasconia, Ob. Cit., p. 226.

155 Enríquez Fernández, J., y Sesmero Cutanda, E., «Representación social y tensiones políticos en las asambleas representativas del Señorío de Bizkaia (c. 1550 - c. 1630)» en (Coord. AA.VV.), Actes del 53 è Congrés de la Comissió Internacional per a l'Estudi de la Història de les Institucions Representatives i Parlamentàries, Ob. Cit., p. 171. 
diados del siglo XVI hasta en torno a 1630 las instituciones centrales vizcaínas padecieron frecuentes enfrentamientos internos como consecuencia de una lucha de bandos que repercutió en la estabilidad de sus Villas ${ }^{156}$. A pesar del clima de inestabilidad interno, hubo algunas reticencias generalizadas hacia los superintendentes en esta época. Tras haber concedido Cristóbal de Barros cierto protagonismo a los corregidores, hemos visto que su sucesor, Ojeda, mantuvo desavenencias con el Señorío. A comienzos del siglo XVII las Juntas vizcaínas le acusaron de sobrepasarse en sus actuaciones, pretendiendo evitar su trato con el superintendente para dejar el asunto forestal en manos de los corregidores. Con este fin solicitaron a sus síndicos que «les den información y averigüen los excesos y agravios que ha hecho el Capitán Agustín de Ojeda» y planteándose enviar un representante ante la Corte para convencer al monarca de este propósito ${ }^{157}$. Por su parte, ante la postura sostenida por la institución vizcaína, Ojeda veía intenciones encubiertas en contra de la Superintendencia, que consideraba podían redundar en detrimento del fomento de árboles:

«La caussa prinçipal que les muebe a que este off". ande en los Corregidores es porque nunca hazen visita personalmente y solo se contentan con que les traigan testimonios de como an plantado algunos en cada año, no lo auiendo echo y assi se alla todo el Señorio muy desnudo de plantios, y por esto tienen miedo que aya algunas condenaçiones $\rangle^{158}$.

Sin embargo, a pesar de las protestas provinciales, pocos años mas tarde, en la Junta General de agosto de 1605, fue leída una cédula del rey, despachada el 12 de julio de aquel mismo año, en la que ordenaba al Señorío ayudar al superintendente en las labores de plantar y mantener robles y fresnos para la fábrica de navíos. En las actas quedó reflejado cómo «se obedeció la real carta y en cuanto a su cumplimiento mandaron que los Síndicos hablen al Capitán Ojeda» ${ }^{159}$.

La colaboración con los requerimientos de la Monarquía continuó ocasionalmente pero actuando el Señorío desde su propio territorio e instituciones, intentando soslayar la presencia de los Superintendentes. Así el territorio se ofreció para actuar en actividades constructivas de barcos con las «Condi-

156 Zabala montoya, M., «Las Juntas Generales de Bizkaia a principios de la Edad Moderna: desequilibrios y enfrentamientos anteriores a la concordia» en Cuadernos de Historia Moderna, $\mathrm{n}^{\circ}$ 30; Servicio de Publicaciones de la Universidad Complutense, Madrid, 2005, pp. 85-124.

157 Acta del Regimiento General, 7 de abril de 1600. Vid. De Sargarmínaga F. y de Areitio, D., El Gobierno y Régimen Foral del Señorío de Vizcaya, Vol. IV, Excma. Diputación Foral de Vizcaya, Bilbao, 1928, pp. 200-201.

158 AGS; G.A.; Leg. 565-62; Agustín de Ojeda a Felipe III. Vizcaya; 21 de abril 1600.

159 Acta del Regimiento General, 7 de abril de 1600. Vid. De Sargarmínaga F. y de Areitio, D., El Gobierno y Régimen Foral del Señorío de Vizcaya, Vol. IV, Ob. Cit., p. 414. 
ciones con que el Señorío de Vizcaya ofrece fabricar ocho navios para servir en la Armada» en 1617. Para ello solicitaron el traslado por parte del rey de 25.600 ducados por vía de empréstito, puestos en Bilbao, con los que poder hacer frente a la nueva construcción, de los cuales 22.600 serían empleados en las pertinentes cortas de maderas, además de preferir la importación de pinos de Prusia o de Riga para las arboladuras de las naves. De cara a las maderas que fuesen propiedad de particulares, debía proporcionársele al Señorío toda la tabla, árboles y demás pertrechos y aparejos existentes en los almacenes de la comarca que solicitara, «por el coste que le tuvieren a S.M., y su valor se descuente del empréstito» ${ }^{160}$. Por este motivo no puede hablarse rotundamente de contienda entre el centro y la periferia, ya que existió cierta colaboración entre ellos, entre los distintos poderes y sujetos agentes del territorio ${ }^{161}$, aunque en este caso al margen de los comisionados de Montes.

Cuestión diferente es que gran parte de las actuaciones de las Juntas no fuesen vistas con buenos ojos por las Superintendencias. A comienzos de la década de los cuarenta la postura de las Juntas Generales vizcaínas, generó tal malestar en quien ocupaba el cargo forestal, Martín de Vallecilla, que manifestó a Felipe IV:

«Los del gouierno deste Señorío, en todas las Juntas generales y particulares tratan de desacreditar este ofiçio dando a entender que solo ellos han de dar las ordenes de los que se ha de hazer. Y anssi en esta ultima Junta han decretado e ymbiado a los lugares autos para que en cada uno aya un Super yntendente de montes y plantios y que se puedan valer de ellos, y puedan dividir los montes // y esto lo fomentan los dueños de las ferrerias por tener mano para hazer lo que quieren ${ }^{162}$.

El superintendente opinaba que, de acceder a las pretensiones del Señorío, «no abria de aquí a diez años pie de arbol ni con que hazer fabricas ni edificios de cassas». Era plenamente consciente que su principal obligación chocaba con los intereses de Vizcaya ya que, desde su nombramiento en 1626, su principal cometido había consistido en «que se planten los montes en el numero de Arboles que a cada lugar y ante Iglesia esta repartido para que se ebiten las desordenes de talas y cortas para que aya maderas nuevas para las fabricas de navios»), rivalizando por la disposición de estos recursos con las poblaciones de la zona ${ }^{163}$. Para poder controlar las actividades forestales de

160 Fernández Duro, C., A la mar madera. Libro Quinto de las Disquisiciones Náuticas, Ob. Cit., pp. 63-69.

161 Fioravanti, M., «Estado y Constitución» en El Estado Moderno en Europa: Instituciones y Derecho, Trotta, Madrid, 2004, p. 29.

${ }_{162}$ AGS, G.A., Leg. 3221. Martín de Vallecilla a Felipe IV, Portugalete, 28 de diciembre de 1642 .

163 AGS, G.A., Leg. 3221. Carta de Martín de Vallecilla a Felipe IV, Bermeo, 11 de noviembre de 1643 . 
los lugareños, se vio obligado a volver a hacer constar en qué consistían sus obligaciones «en el titulo que V.M. me mando despachar se previene que se haga la visita General dos veces cada año por lo menos»; aunque él mismo reconocía que la aplicación nunca fue así en la práctica, pues «por escusar molestias he dejado de haçer continuas visitas pero siempre que e reconocido que combiene las e executado». Sobre las visitas manifestaba también que en todo momento las hizo «juntandome con la justicia hordinaria de los lugares», quienes le mostraban los términos del municipio empleados para los plantíos, lo que siempre se había «hecho por mi y por mis anteçessores» ${ }^{164}$. Situación similar, pero aún más acentuada, fue la vivida en la otra región costera vasca, que trataremos a continuación.

\subsection{Guipúzcoa}

El área que más conflictos mantuvo con los superintendentes de Montes y Plantíos, y de la que más documentación se generó como consecuencia de su alta actividad astillera, fue Guipúzcoa. Ésta contó con numerosos centros de producción que construyeron importantes unidades navales para la Corona $^{165}$, y en ella ya existía alguna zona esquilmada a fines del siglo XVI. Los recelos se tradujeron en una frecuente inobservancia de las disposiciones dictadas por las Superintendencias ${ }^{166}$.

Tras el cese de Barros los asuntos de montes recayeron en torno a 1597 sobre la figura del ya citado Antonio de Urquiola ${ }^{167}$. Desde el inicio de su actividad las relaciones de Urquiola con la Provincia no fueron fluidas, oponiéndose constantemente esta última a sus actuaciones ${ }^{168}$. Ante estas reticencias tampoco fueron infrecuentes las protestas del nuevo comisionado dirigidas al rey acerca de la falta de colaboración en todo lo referente a la construcción naval, acusando a las villas que la conformaban de negarse a cooperar en el acarreo de la madera y que le obligaron a elevar quejas alegando que «recaudo he ymbiado diversas bezes a guipuzcoa y al corregidor» sin obtener respuesta satisfactoria ${ }^{169}$. Anteriormente expusimos que los problemas surgieron en torno a 1597, cerrando las diversas villas sus puertas a todos los

${ }^{164}$ Ibídem.

165 Odriozola Oyarbide, L., «La construcción naval en Guipúzcoa. Siglos XVIXVIII» en Itsas Memoria. Revista de Estudios Marítimos del País Vasco, no 2, Ob. Cit., p. 93.

166 Aragón Ruano, A., El bosque guipuzcoano en la Edad Moderna: aprovechamiento, ordenamiento legal y conflictividad, Ob. Cit., p. 165

167 AGS, G.A., Leg. 484-54, 490-106, 490-123, 490-127. Goodman, D., El Poderío naval español. Historia de la Armada del siglo XVII, Ob. Cit., p. 369. Gómez Rivero, R., «La Superintendencia de construcción naval y fomento forestal en Guipúzcoa (15981611)» en A.H.D.E., nº 56, Ob. Cit., p. 162 y pp. 601-606.

168 Gómez Rivero, R., «La Superintendencia de construcción naval y fomento forestal en Guipúzcoa (1598-1611)» en A.H.D.E., nº 56, Ob. Cit., p. 163.

169 AGS, G.A., Leg. 490-106. Antonio de Urquiola a Felipe II, Lezo, 4 de octubre de 1597. 
foráneos, incluyendo a los comisionados regios, por una epidemia de peste entre San Sebastián y Pasajes. A este respecto, Guipúzcoa alegó en defensa de los intereses de sus municipios que siempre había cumplido con las órdenes y cédulas recibidas, cuidando que todos sus vecinos hiciesen plantíos comprendidos dentro de las dos leguas próximas a la mar o ríos navegables $\mathrm{y}$ asegurando tener constancia de su observancia porque «cada Villa y lugar dan sus testimonios de auerlo cumplido cada año a las Juntas Generales que celebramos despues de la pascoa de resurresion». Valiéndose de la misiva, la Provincia aprovechó para quejarse de los impagos sobre los árboles cortados por la Corona, que hacían peligrar la continuidad de nuevas plantaciones tanto a nivel concejil como particular, haciendo ver que tales deudas influirían negativamente en las pretensiones políticas de la Monarquía, «de que redundaria Gran Desserviç ${ }^{\circ}$. a V.Magd. Asi para sus Reales Armadas como para el trato y comerçio de sus reynos» ${ }^{170}$.

Tras la peste de 1597, los conflictos con la Superintendencia de Urquiola no cesaron, antes al contrario, durante los primeros años de su mandato las fricciones aumentaron. La crónica de los hechos es la siguiente y resulta lo suficientemente representativa de las disensiones entre el comisionado regio y la asamblea.

Así, en septiembre de 1598 también fueron efectuados repartos de plantíos entre las villas pero muy pocas cumplieron el mandato, elevando nuevamente quejas al órgano representativo de la Provincia ${ }^{171}$. Poco después, durante la Junta de Guetaria, de 20 de noviembre de 1598, el concejo de Astigarraga manifestó que, a pesar de que Urquiola había ordenado un repartimiento de plantíos sobre sus terrenos concejiles, la institución local no disponía de propios, ni otras rentas, ni tampoco de un lugar en el que poder plantar los robles indicados, por lo que solicitó que mientras se informaba a la Corona la asamblea decretara que la Superintendencia no obligara en el asunto a dicho concejo ${ }^{172}$. La solicitud fue leída en la propia Junta acordán-

170 AGS, G.A., Leg. 426-156. La Provincia de Guipúzcoa a Felipe II, Tolosa, 18 de abril de 1598. Nuevamente el motivo de las quejas tuvo su origen en la villa de Rentería, donde se cortaron «cantidad de Robles diziendo que importaua se cortasen en aquel menguante de Ebrero y todo ello sea cortado en el monte Brauo de la dha Villa donde los vezinos della no tiene aprouecham ${ }^{\circ}$. sino el comun en voz del concejo. Y que han dado certificaçiones dello para que se les pague su prescio, a que tienen enbiado persona y que de dilatarse su resoluçion resiguen daño y se desanimaran a continuar los plantios asi en la dha Villa como en el resto de la provincia»».

${ }^{171}$ Un análisis de estos años sobre Guipúzcoa, comprendidos entre fines del s. XVI y comienzos del XVII, es recogido por Gómez Rivero, R., «La Superintendencia de construcción naval y fomento forestal en Guipúzcoa (1598-1611)» en A.H.D.E., n ${ }^{\circ}$ 56, Ob. Cit., pp. 601-606. También sigue a éste ARAGón RuAno, A., El bosque guipuzcoano en la Edad Moderna: aprovechamiento, ordenamiento legal y conflictividad, Ob. Cit., p. 165.

${ }^{172}$ Gómez Rivero, R., «La Superintendencia de construcción naval y fomento forestal en Guipúzcoa (1598-1611)» en A.H.D.E., n 56, Ob. Cit., p. 603. Cita A.G.G., J.G. de Guetaria, 20-XI-1598. 
dose, que en virtud de las diversas disposiciones emanadas de Felipe II, se había ordenado que sus villas plantasen una cantidad determinable de robles y otros árboles. Guipuzcoa, por su parte, indicó que todo esto se había estado cumpliendo en los años anteriores, tal y como constaba en los testimonios mandados por las villas en las Juntas anuales que se celebraban en verano. Dados estos antecedentes la asamblea resolvió obedecer y reverenciar la Real Cédula de plantíos ${ }^{173}$, pero decidió permanecer exenta de su cumplimiento de acuerdo con el pase foral ${ }^{174}$. Además pidió al rey que no mandase desposeer de los autos originales a los escribanos de la Provincia por los «generales u otros ministros de guerra", sino que a éstos se les proporcionasen traslados "signados para que en todo aya siempre cuenta y raçon» ${ }^{175}$.

Tres días más tarde Antonio de Urquiola remitió escrito a la Junta con el fin de que ésta ordenase a las villas guipuzcoanas que le mandasen relación con la cantidad de repartimientos hechos a los particulares. Sin embargo, la institución provincial no sólo no se plegó a esta solicitud sino que acordó una providencia en materia de plantíos mediante la que compelía a todos los alcaldes ordinarios el envío a las Juntas del verano de los testimonios de cada plantío hecho en su jurisdicción. Además se decidió acudir al rey para que dispensara a la propia Junta y pudiese hacerlo ella por sí misma, quedando exenta de los mandatos del superintendente u otras comisiones del mismo tipo. Por el contrario, Urquiola se mostró reticente a acceder a las pretensiones de la institución provincial, manifestando a Felipe III que:

${ }^{173}$ Ibídem, p. 603. El autor supone que tal vez se trate de la Real Provisión de 1548. Sin embargo, no manifiesta conocer la Real Cédula de 7 de diciembre de 1574 y la Instrucción de 1575, pues sólo afirma saber sobre Cristóbal de Barros que fue Superintendente antes de 1598. Nos inclinamos más por que se trate alguna de estas normas ya que son más cercanas en el tiempo y, sobre todo en la materia, que no se refieren a meros asuntos forestales sino a éstos mismos aplicados a las necesidades navales.

${ }_{174}$ Ayerbe Iríbar, Ma . R., «Las Juntas Generales vascas. En defensa de la foralidad y de los derechos históricos» en Ivs Fvgit, n 15, Ob. Cit., p. 310. Afirma que «El pase foral suponía la revisión de todas las cartas y provisiones reales de aplicación en el territorio y la orden dada por ésta para su cumplimiento. Conocido como concesión de uso o pase foral, su objetivo era evitar que se diese algún contrafuero. La fórmula del obedézcase pero no se cumpla suponía la suspensión del cumplimiento de la orden y la devolución de la real disposición a la consideración del Rey para que enmendara todo aquello que podía ser en perjuicio de la foralidad establecida».

175 Gómez Rivero, R., «La Superintendencia de construcción naval y fomento forestal en Guipúzcoa (1598-1611)» en A.H.D.E., n ${ }^{\circ}$ 56, Ob. Cit., pp. 602-604. Afirma que «El motivo de esta petición tenía su origen en que el superintendente había hecho un repartimiento de plantíos, por presencia de Pedro del Puerto, escribano numeral de Guetaria, y se había llevado los autos originales del repartimiento». En esta misma asamblea, el municipio en donde se estaba celebrando, Guetaria, mostró su disconformidad frente a la postura mantenida por las demás villas. Sin saber las causas, esta villa manifestó su obediencia a la Real Cédula y «que está presto a facer cumplir lo que por ella se manda» (A.G.G., J.G. de Guetaria, 20-XI- 1598). 
«Todos los días pasado tengo escripto a V.M. dando quenta (...) de lo que esta señalado y Repartido los plantíos de robles y fresnos a las Villas y lugares de la costa desta provincia y la contradicion que han querido poner en nombre de Guipuzcoa para suplicar a V.M ${ }^{\mathrm{d}}$. que no se entienda con ellos tomando por ocasion que en la rreparticion que hize hauia señalado demasiado y no seria razón que se diese lugar a que se escusen de plantar conforme como esta Repartido. V.M ${ }^{\mathrm{d}}$. mandase pues importa tanto a su rreal seruicio y particular Bien y hutilidad de toda esta Tierra» ${ }^{176}$.

En estas circunstancias, el rey emitió una Real Cédula, fechada en Madrid el 5 de enero de 1599 y ya citada en páginas anteriores, en la que exponía cómo el superintendente se quejó de las pretensiones guipuzcoanas por acaparar para sí la ejecución de los plantíos ${ }^{177}$, así como la postura regia que intentó apaciguar la controversia «de manera que se haga lo que conuiene y sea con la mayor breuedad y menos pesadumbre de los vecinos» ${ }^{178}$. Según Gómez Rivero, este testimonio pone de manifiesto la buena disposición del monarca en el asunto de los plantíos, sobre el que deseaba su ejecución pero sin generar perjuicios a los guipuzcoanos. La cédula fue remitida, tras su estudio en la Diputación de Azcoitia, a los valles, villas y alcaldías de la Provincia para que expresaran su opinión, además de acordar que todas las poblaciones despachasen testimonios de los plantíos en la siguiente Junta de verano que se celebraría en Cestona ${ }^{179}$. Una de las primeras medidas de dicha Junta fue la de ordenar, el 26 de abril de 1599, que cada procurador aportase a ésta los testimonios de los plantíos hechos dentro de sus términos durante el referido año, lo que pondría de manifiesto que la asamblea provincial no contemplaba la posibilidad de remitirlos a la Superintendencia, a pesar de que así lo disponía la comisión regia. Con posterioridad, el 3 de mayo, Urquiola se presentó en la Junta exhibiendo la Real Cédula de 5 de enero de 1599 y la orden referente a los plantíos. Las dos normas se leyeron y en la jornada siguiente fue acordada una disposición mediante la cual la Provincia remitiría a Felipe III la orden que desde ella se había dado a todas sus villas encargando la plantación en cada una de ellas de una cantidad mínima de 500 robles, debiendo enviar testimonio de su ejecución, y que sumarían alrededor de 15.000 pies de árboles anuales, con apercibimiento de imponérseles la

176 AGS, G.A., Leg. 522-154, Antonio de Urquiola a Felipe III, Pasajes, 8 de diciembre de 1598 .

177 Copia de ella en AMN, Vargas Ponce, T. $3^{\mathrm{a}}$, Doc. 31, Fol. $167 \mathrm{r}^{\mathrm{o}}$.- 168 r $^{\mathrm{o}}$. Original en A.G.G., Sec. $2^{\text {a }}$, Neg. 17, Leg. 11.

178 AMN, Vargas Ponce, Ms., 75 / 031 (fols. 167-168). Real Cédula dirigida a Guipúzcoa para que trate con Antonio de Urquiola de la forma de ejecutar las ordenanzas sobre plantíos, Madrid, 5 de enero de 1599.

179 Gómez Rivero, R., «La Superintendencia de construcción naval y fomento forestal en Guipúzcoa (1598-1611)» en A.H.D.E., n 56, Ob. Cit., cita A.G.G., Registro de actas de la Diputación desde 29-XI-1598 hasta el 24-III-1599. 
pena de 10.000 maravedíes, ya establecida durante el período de Cristóbal de Barros $^{180}$. También fue acordado el aporte de maderas particulares para la real fábrica, pero pidieron que éstas fuesen tasadas antes de cortarse, debiendo evaluarlas «sendas personas nombradas por el que tuviere a su cargo la dicha fabrica y por el dueño de los tales maderos». Además dispusieron suplicar a la Corona evitar la Superintendencia y que, cuando el rey lo considerase oportuno, se le enviarían desde allí los testimonios necesarios para justificar el cumplimiento de las plantaciones. Sobre esta petición no se pronunció Felipe III y al poco, en verano de 1600, como ya apuntamos en páginas precedentes, falleció Urquiola.

Al comienzo de este nuevo período Guipúzcoa siguió observando la antigua Ordenanza de 1548 y las villas enviaron su testimonio en abril de $1601^{181}$. Poco después, al encontrarse vacante la ocupación de la fábrica de navíos y conservación de montes en la Provincia, se nombró para su gobierno y administración, en julio de 1601, al coronel Domingo de Idiáquez ${ }^{182}$. Sus funciones eran, genéricamente, las mismas que las de su predecesor, señalando el número y calidad de los ejemplares a plantar entre los pueblos. También se le ordenó disponer con orden y medida los que eran susceptibles de ser desmochados y cortados, destacando ahora la obligación de enviarle al rey una relación anual de los árboles que hubiese repartido en cada término concejil. Ésta se la podrían proporcionar los alcaldes, quienes debían entregarle los testimonios de todo lo plantado en sus jurisdicciones para que a su vez el coronel los remitiese al veedor y contador de la gente de guerra de las villas de San Sebastián y Fuenterrabía, Martín de Aróstegui. Al poco tiempo, en el mes de septiembre de aquel mismo año, el nuevo superintendente ya desempeñaba sobre el terreno sus funciones, recorriendo lugares y villas situados a dos leguas de la mar mandando el plantío de robles para el mes de marzo del año siguiente, 1602.

La forma en la que ordenó su establecimiento era la de mantener una distancia de ocho codos de separación entre ejemplares, supervisando que creciesen rectos. Con el fin de obtener la materia prima más adecuada para la

180 Gómez Rivero, R., «La Superintendencia de construcción naval y fomento forestal en Guipúzcoa (1598-1611)» en A.H.D.E., n 56, Ob. Cit., p. 606. En p. 624 recoge la trascripción del acuerdo de la Junta de Cestona, aprobado en 4 de mayo de 1599 (A.G.G., Registro de Juntas de Cestona de mayo de 1599) Aragón Ruano, A., El bosque guipuzcoano en la Edad Moderna: aprovechamiento, ordenamiento legal y conflictividad, Ob. Cit., p. 165.

${ }^{181}$ Aragón Ruano, A., El bosque guipuzcoano en la Edad Moderna: aprovechamiento, ordenamiento legal y conflictividad, Ob. Cit., p. 165.

182 AMN, Vargas Ponce, Ms., 75 / 031 (fols. 170-175) Copia fehaciente de Real Cédula encargando a Domingo de Idiáquez de la fábrica y arqueamientos de navíos de Guipúzcoa, así como de la conservación de los montes de dicha provincia, por muerte del general Antonio de Urquiola, Valladolid, 21 de julio de 1601. Gómez Rivero, R., «La Superintendencia de construcción naval y fomento forestal en Guipúzcoa (1598-1611)» en A.H.D.E., n ${ }^{\circ}$ 56, Ob. Cit., p. 606. 
construcción naval, Idiáquez mandó que se escogieran los mejores plantones que dispusiesen los viveros. Por otro lado, de cara a las actividades forestales de los pobladores estableció que tanto el concejo como los particulares que cortasen o hubieren cortado robles antiguos para la fabricación de viviendas, naos u otra obra, plantaran en su lugar dos robles por cada ejemplar cercenado. Por último, el superintendente formulaba el apercibimiento de que en la siguiente visita ejecutaría las penas dispuestas en su comisión sobre los infractores ${ }^{183}$. Sin embargo, los lugares sujetos a la jurisdicción de Idiáquez no estuvieron muy de acuerdo con la visita, y tanto el valle Oyarzun como San Sebastián elevaron a la Diputación sus protestas. El primero refería, por carta de 14 de septiembre, que el coronel, tras llegar a la zona y haber exhibido su comisión, pidió verbalmente que le dijesen cuántos árboles podían plantar el concejo y los particulares. Asimismo, este valle comunicaba que no había querido resolver ni dar respuesta a Idiáquez hasta que la Diputación tuviese conocimiento de todo el asunto. Por su parte, al siguiente día, 15 de septiembre, la villa de San Sebastián también se dirigió a la misma institución trasladándole la cédula real, refiriéndose a la orden dada por el superintendente acerca de la ejecución de los plantíos y los apercibimientos hechos a la población en caso de ser remisos en el cumplimiento de su orden ${ }^{184}$. Tres días más tarde fue leída la carta de la villa en la Diputación y se acordó escribir al coronel para que suspendiera la ejecución de su comisión hasta la celebración de la próxima Junta, a celebrar en Azcoitia, donde se trataría el asunto y se daría la orden que fuere considerada más conveniente «al servicio de su magestad de bien de esta republica» ${ }^{185}$.

Respecto a este modo de proceder, Gómez-Rivero hace hincapié en resaltar cómo el superintendente Idiáquez no presentó la cédula real de su oficio o pase de la Provincia. Así pues, la Diputación había de conformarse con un traslado de la comisión remitido por la villa de San Sebastián porque en ningún momento la institución guipuzcoana obtuvo de Idiáquez la cédula. Sin embargo, el comisionado de la Corona sí procedió exhibiendo directamente su comisión en aquellas villas donde hizo el repartimiento de árboles ${ }^{186}$.

En la Diputación de Tolosa también se vio, el 18 de septiembre, una relación de lo que consideraba la villa de San Sebastián-Oyarzun remitió otra semejante- que debería realizarse con los plantíos, difiriendo de lo ordenado por el superintendente y que constaba de tres puntos:

183 Gómez Rivero, R., «La Superintendencia de construcción naval y fomento forestal en Guipúzcoa (1598-1611)» en A.H.D.E., n 56, Ob. Cit., pp. 606-607.

184 AMN, Vargas Ponce, Ms., 86 / 18 (fol. 38), San Sebastián 15 de septiembre de 1601 (copia del original del Archivo de Guipúzcoa).

185 Gómez Rivero, R., «La Superintendencia de construcción naval y fomento forestal en Guipúzcoa (1598-1611)» en A.H.D.E., nº 56, Ob. Cit., p. 608. Cita A.G.G., Diputación de Tolosa, 15-IX-1601.

${ }^{186}$ Ibídem, p. 608. 
«1.- Que al alcalde y regimiento no se les podía compeler a la ejecución del repartimiento que se hacía a los particulares porque era el coronel, en virtud de su comisión, quien tenía que encargarse de dicha ejecución. Por ello se debía de suplicar al Consejo de Guerra en este asunto.

2.- Que los árboles se plantaran por lo menos a 10 codos de distancia y no a ocho como proponía Idiáquez.

3.- Que cuando se cortaran robles viejos, sería suficiente que se plantara uno en lugar de que se cortara» ${ }^{187}$.

El 20 de noviembre de 1601, las Juntas Generales de Azcoitia acordaron escribir al rey acerca de las providencias adoptadas por la Provincia respecto de los plantíos y suplicar el cese del cargo de superintendente ${ }^{188}$. Sin embargo, la intención real era claramente opuesta a la petición y una real cédula, otorgada en Valladolid el 29 de noviembre de 1601, declaraba en su parte expositiva que la villa de San Sebastián no había obedecido el repartimiento ordenado por Idiáquez alegando que se oponía a una ordenanza provincial. En la parte dispositiva se reprobaba la legislación guipuzcoana mandando que cumpliera fielmente las órdenes dadas por Idiáquez sin que cupiese ningún tipo de alegación o interpretación de la ordenanza. Felipe III era taxativo:

«...mando que en esta conformidad hagais de vuestra parte el esfuerzo neçesario para ello asistiendo al dicho coronel con el favor y ayuda y los otros medios que para este efecto os pidieredes dar, conforme al amor y zelo que teneis a mi serviçio» ${ }^{189}$.

El asunto sobre el que versaba la disposición regia fue considerado de tanta entidad, al entender que vulneraba los intereses provinciales, que se decidió no tratarlo en sede de la Diputación, y al quedar aún cuatro meses para la celebración de la Junta de verano, fue objeto de una Junta particular celebrada dos días después de año nuevo en Basarte. La Provincia no cedió en sus pretensiones y sus junteros, aplicando la fórmula del pase foral, decidieron obedecer la susodicha carta real, pero en lo atinente a su cumplimiento, dijeron que suplicaban de ella, lo que a efectos prácticos suponía volver a acatar la Ordenanza provincial de montes de $1548^{190}$.

En marzo de 1602 Idiáquez tenía que haber llevado la segunda visita a las villas costeras, tal y como había anunciado, pero prefirió esperar a la

187 Ibídem, p. 609 (pie de página 78). Cita A.G.G., Diputación de Tolosa, 18-IX-1601.

188 Aragón Ruano, A., El bosque guipuzcoano en la Edad Moderna: aprovechamiento, ordenamiento legal y conflictividad, Ob. Cit., p. 165.

189 Gómez Rivero, R., «La Superintendencia de construcción naval y fomento forestal en Guipúzcoa (1598-1611)» en A.H.D.E., n 56, Ob. Cit., p. 611. Cita A.G.G., Sec. 2a, Neg. 17, Leg. 11.

${ }^{190}$ Ibídem, pp. 611-612. Cita A.G.G., Registro de la Junta Particular de Basarte, 3 de enero de 1602. De la Cruz Aguilar, E., La Destrucción de los Montes (Claves históricojurídicas), Ob. Cit., p. 81. 
celebración de la siguiente Junta de abril, en Zumaya, aguardando para ver si ésta llegaba a adoptar algún acuerdo en el asunto. A pesar de las decisiones en contrario de la Junta, el coronel comunicó a la asamblea su necesidad de enviar al monarca los testimonios municipales sobre los plantíos. Sin embargo, los alcaldes los remitieron al órgano provincial, sin pasar por el comisionado regio y obstaculizando de este modo el ejercicio de la Superintendencia. Aún así, Idiáquez decidió cumplir las obligaciones de su cargo sin considerar los acuerdos junteros. De este modo, y a pesar del retraso, resolvió visitar las villas bajo su jurisdicción actuando con firmeza en los lugares donde no se hubiesen cumplido sus órdenes, como el caso de Azpeitia, donde en julio de 1602 multó a los oficiales de su regimiento con 1.000 reales por no haber efectuado el plantío. Durante aquel verano acudió en varias ocasiones al litoral guipuzcoano pero continuó hallando impedimentos, por lo que en noviembre decidió escribir a la Junta de Fuenterrabía para lograr apoyos en la ejecución de sus obligaciones. La Provincia se negó a colaborar, respondiéndole que sus villas continuarían remitiendo los testimonios de sus plantíos a la Junta de verano, manifestándole que Guipúzcoa tenía dada orden a sus villas de cómo tenían que actuar acerca de lo «que tanto importa al servicio de su magestad y al bien desta republica y propio interés de los vezinos della a que se acudirá con la voluntad y beras que el caso requiere y se a hecho siempre» ${ }^{191}$. Idiáquez, cansado de polemizar, escribió al rey lamentándose por no poder llevar a cabo su cometido y Felipe III respondió a la Provincia pidiendo que no trabase las obligaciones del superintendente. No obstante, a pesar de las quejas, Guipúzcoa no dejó de perseverar en su actitud y en la Junta de Vergara fueron leídas dos cartas, una del coronel y otra del rey, sin acceder a sus pretensiones. En efecto, nuevamente las villas entregaron testimonios de los plantíos a la institución provincial, en vez de disponerlos a favor de Idiáquez.

Las constantes pugnas entre la Superintendencia y Guipúzcoa llegaron a enquistarse como consecuencia de la obstinación de las dos partes. Dos años más tarde, desde la Junta de mayo de 1604, en Tolosa, se comunicó a la Corona el cuidado que ponía la Provincia acerca del asunto de los plantíos, enviando otra vez ella misma al rey y no Idiáquez, los testimonios que ese año se habían hecho. Además, la asamblea acordó que en caso de que el coronel procediese contra alguna villa, sus oficiales o los particulares, la intitución provincial pudiera salir en su defensa ante «las bexaciones y molestias que cada dia se ban aumentando» ${ }^{192}$. Ante la inmovilidad de las posiciones, que no permitían desarrollar correctamente el cometido asignado a la Superintendencia, Idiáquez optó por ir a la Corte y solicitar ser relevado de su cargo. Se desconoce si éste era el verdadero motivo de su presencia

191 Gómez Rivero, R., «La Superintendencia de construcción naval y fomento forestal en Guipúzcoa (1598-1611)» en A.H.D.E., n 56, Ob. Cit., p. 613. Cita a A.G.G., J.C. de 23-XI-1602.

192 Ibídem, p. 613. Cita a A.G.G., J.C. de Tolosa, 8-V-1604. 
en Madrid o si tan sólo se trató de una medida de presión, pero, en cualquier caso, Felipe III debió ratificarle, pues en 1606 seguía requiriendo el apoyo de la Provincia. El 13 de abril de aquel año el coronel acudió a las Juntas de Elgóibar exhibiendo dos Reales Cédulas, la primera de ellas refería su nombramiento como responsable de la fábrica de navíos y de la visita de montes, y en la segunda se le ordenaba obligar a los concejos y lugares ubicados a cinco o seis leguas de Placencia a plantar fresnos y nogales para cajas de arcabuces y mosquetes ${ }^{193}$. Ignoramos el sentido del dictamen de la Junta. Si seguimos otra vez el parecer de Gómez-Rivero, no sería descabellado pensar que la postura guipuzcoana permaneciese firme, pues el 12 de septiembre del mismo año el superintendente escribió una misiva a la Provincia en la que le compelía a seguir sus mandatos, amenazándola con actuar severamente:

«Con licencia de V.S. me es fuerça volver por mi reputación y obligación y dar la buena quenta que he dado toda la vida, de lo que tengo a cargo y su magestad me manda. Y que si yo hiçiere algunos papeles, en raçon desto, y acudiere a sacar prendas para las penas que su magestad tiene mandado, y hiciere otras diligencias que me tocan y se inbiaren a su magestad para que mande probeer lo que mas su serviçio fuere, se sirva V.S. del enorme por escusado y disuel [roto], pues de mi parte ha avido toda la buena correspondencia que soi obligado y devo a yjo de V.S. Y de la de los que han faltado de cumplir con las ordenes de su magestad y no han querido acudir con los testimonios, no avrá disculpa, pues no lo es el deçir que los an enviado a V.S., ni con esto cumplen con la voluntad de su magestad, de que a mi me pasa en el alma y de que me obliguen a ejecutar mi orden por rigor» ${ }^{194}$.

Ahora bien, lo que en Guipúzcoa no existía, a semejanza de Vizcaya, era una negativa frontal a colaborar con las necesidades bélicas de la Monarquía, sino a que por las guerras reales se prescindiese de sus instituciones provinciales. De contar con ellas, usualmente había buen entendimiento entre la Corona y los dos territorios y en caso contrario resolvía, en este tipo de casos, el Consejo de Guerra ${ }^{195}$. Prueba de estas avenencias

193 Aragón Ruano, A., El bosque guipuzcoano en la Edad Moderna: aprovechamiento, ordenamiento legal y conflictividad, Ob. Cit., p. 165. Gómez Rivero, R., «La Superintendencia de construcción naval y fomento forestal en Guipúzcoa (1598-1611)» en A.H.D.E., n ${ }^{\circ}$ 6, Ob. Cit., pp. 614-615. Cita A.D.S.S., J.G. de Elgóibar, de 13 de-IV-1606.

${ }^{194}$ Gómez Rivero, R., «La Superintendencia de construcción naval y fomento forestal en Guipúzcoa (1598-1611)» en A.H.D.E., nº 56, Ob. Cit., p. 616 (pie de pág. nº 112). Cita A.G.G., Sec. $2^{\text {a }}$, Neg. 13, Leg. 12.

195 Ayerbe Iríbar, M ${ }^{a}$. R., «Las Juntas Generales vascas. En defensa de la foralidad y de los derechos históricos» en Ivs Fvgit, n ${ }^{\circ} 15, O b$. Cit., p. 310. Opina que «en general hubo siempre un respeto y entendimiento mutuo entre el Rey y los territorios y no se crearon situaciones de conflicto por el ejercicio de este derecho al pase. Pero siempre 
la encontramos en las actuaciones del capitán Domingo de Goyçueta, natural y vecino de Rentería, quien fue uno de los constructores navales más activos de aquel municipio guipuzcoano. En sus comienzos se había dedicado a la fabricación de embarcaciones particulares, pero desde 1606, tal vez al amparo de subvenciones reales, firmó varios contratos de asientos con la Corona para la labra de navíos destinados a las Armadas del Mar Océano, entre los que consta un contrato, en 1606, para la construcción de tres galeones de guerra y otro, dos años más tarde, por otros tantos navíos con el mismo destino. Ambos contratos fueron llevados a cabo con árboles provenientes de los montes concejiles de Rentería y en este caso la villa no le puso ningún impedimento para su venta al entender que estos negocios madereros potenciaban su industria naval, uno de los principales pilares económicos de la población ${ }^{196}$.

La colaboración fue algo mayor tras el nombramiento como superintendente de Domingo de Echeverri, en abril de 1611. Éste comenzó a actuar en materia de construcción naval, no viniendo a desempeñar efectivamente sus competencias sobre Montes hasta que se reuniese la Junta de Guipúzcoa para poder notificarle su acceso al cargo. Ésta tuvo lugar en Fuenterrabía, y el 16 de noviembre se presentó Echeverri entregando un memorial firmado de su puño y letra en el que exponía lo que consideraba que debía llevar a cabo la Provincia para el fomento forestal, así como su conservación para fábrica de navíos y provisión de ferrerías. El nuevo superintendente requirió a la asamblea que leyera este documento y que en razón de él acordase lo más conveniente a los intereses generales y al bien provincial. Además exigió a la Junta que pidiese a las villas, alcaldías y valles que le proporcionasen los testimonios de plantíos, advirtiendo que, en caso contrario, emplearía los recursos necesarios. El órgano guipuzcoano agradeció la consideración que había tenido Echeverri «en hacer merced» con las informaciones y prevenciones de su escrito «acudiendo a esta Junta como tan buen hijo de esta provincia» -trámite que su predecesor en el cargo había pasado por alto- para posteriormente ordenar a los procuradores de San Sebastián, Deva y Oyarzun

que se hubo de aplicar alguna disposición real en ellos, a pesar de habérseles aplicado el pase (y fueron escasas las ocasiones), se procuró llegar a arreglos o avenencias entre la Corona y los territorios dándoseles el nombre de avenencias, pactos o conciertos que, consentidas por las partes, adquirían la misma fuerza y vigor que los fueros». Si bien en ocasiones, el «puntual ejercicio de esta competencia por parte de la Provincia originó no pocos conflictos con otros jueces, especialmente con el Corregidor o el Capitán General de Guipúzcoa, al no estar del todo bien recogidos por el Fuero los límites de sus atribuciones, resolviéndose las diferencias en última instancia por los Consejos Reales de Guerra o Justicia, según fuese la materia del delito y la conveniencia del momento».

196 Odriozola Oyarbide, L., «La construcción naval en Guipúzcoa. Siglos XVIXVIII» en Itsas Memoria. Revista de Estudios Marítimos del País Vasco, $\mathrm{n}^{\mathrm{o}}$ 2, Ob. Cit., p. 119. 
que analizasen el documento disponiendo lo más conveniente ${ }^{197}$. Dos días después fue leído el dictamen de los junteros y esta vez sí se accedió a cumplir el memorial. En la misma Junta fue decretado que los lugares entregaran al superintendente los testimonios de los plantíos ${ }^{198}$.

Pocos años más tarde la actividad naval también se incrementó, a la vez que se produjo un cambio de superintendente. Sabemos que el encargado de la fabricación de galeones al servicio de la Corona en el Señorío de Vizcaya había venido siendo anteriormente el Capitán Agustín de Ojeda, natural de Fuenterrabía, y también superintendente forestal. Su labor fue estimada y le sirvió para que Felipe III en 1617 le pusiese al frente de las fábricas, plantíos y montes de Guipúzcoa ${ }^{199}$. Poco después, el 8 de mayo de 1618, esta Provincia se ofreció a construir doce galeones para la Corona lo que fue aceptado por el rey mediante Real Cédula de 28 de julio ${ }^{200}$. Sin embargo, los problemas no cesaron. Para llevar a cabo esa construcción de barcos, la villa de Hernani tuvo que pedir que sus montes no fuesen esquilmados por personas ajenas a la misma:

«Fran ${ }^{\mathrm{co}}$. de Oña en nombre de la Villa de Ernani digo que algunas personas por orden de los fabricadores de Nabios ô Galeones socolor de que para su fabrica pueden de su autoridad tomar los Arboles y maderos necesarios en qualquiera Jurisdicion pagando su valor han rescibido algunos Montes de la dha Villa y señalado con les sin licencia ni consentimiento de los del Regimiento y se teme que tomaran atrevimiento de cortarlos por asegurarse a su parecer a lo qual nos e debe dar lugar y aunque pudiera la dha villa querellarse criminalmente contra los tales por lo hecho pide y suplica a V.S. que pues tiene aceptado el ofrecimiento que le ha hecho de dos Galeones y para ellos tiene mucha necesidad de toda su arboleda y maderamen tomando este negocio por suio se sirba de hacer instancia con el señor correx ${ }^{\text {or }}$. para que mande despechar su mandamiento contra queles quier fabricadores y persona que so grabes penas no toquen los dhos montes ni Arboles de la Jurisdicion de la dha Villa la qual recibira merced y fabor en ello». ${ }^{201}$

197 Gómez Rivero, R., «La Superintendencia de construcción naval y fomento forestal en Guipúzcoa (1598-1611)» en A.H.D.E., nº 56, Ob. Cit., pp. 621-622. Cita A.D.S.S., J.G. de Fuenterrabía, de 17 de noviembre, pp. 17-18.

${ }^{198}$ Ibídem, p. 622.

199 Odriozola Oyarbide, L., «La construcción naval en Guipúzcoa. Siglos XVIXVIII» en Itsas Memoria. Revista de Estudios Maritimos del País Vasco, n 2 , Ob. Cit., 111.

200 Fernández Duro, C., A la mar madera. Libro Quinto de las Disquisiciones Náuticas, Ob. Cit., pp. 69-70.

201 AMN, Colecc. Vargas Ponce, Ms., 75 / 73 (fol. 281). Representación de la villa de Hernani para que el Corregidor de Guipúzcoa prohíba a los fabricantes de navíos de otras 
A pesar del agotamiento y de las reticencias que despertaban los superintendentes, desde Guipúzcoa se continuaron haciendo esfuerzos para proveer de materiales la construcción de uno de los galeones que estaría al frente de las unidades atlánticas. Este empeño hizo que la propia Monarquía agradeciese el gesto:

\section{«El Rey.}

Junta Procuradores Caballeros hijos dalgo de la mui noble y mui leal Prouincia de Guipuzcoa. El Corregidor Don Pedro de la Barreda Zeballos me ha dado quenta en carta de los veinte y uno de Diciembre de la promptitud con que haueis dispuesto que se den los Arboles que me teniades ofrecidos para la tablazón de la Capitana que he mandado se fabrique en los Astilleros de la Villa de San Seuastian para mi Armada del mar océano por lo qual os doy muchas gracias asegurandoos que tendre memoria desto en todas las ocasiones ${ }^{202}$.

La doble preocupación por el esquilmo de los bosques, regia por un lado y de las villas guipuzcoanas por otro, volvió a representarse en la Junta de Azcoitia de 1657 en pugna por abastecer a las Armadas o a las ferrerías. Ante el conflicto de intereses la Corona respondió que lo principal que «importaba al bien comun de la Monarquia la conservazion de los Montes y plantios de la dicha Provincia, de que se fabricavan los navíos de mayor fuerza y porte para las Armadas y Carrera de Indias», a la par que intentaba conciliar esta necesidad bélica con las prácticas tradicionales ferronas puesto que «de los dichos plantios y conservazion de los montes no sólo resultava la madera, sino que el desecho servía para carbón de que se yba sintiendo falta en las herrerías $\rangle^{203}$.

De todas maneras, los intentos por parte de la Corona para armonizar las explotaciones forestales continuaron sin dar todos los frutos deseados. En 1668, otro superintendente, Luis de Necolalde, volvió a toparse con recelos generalizados en toda la Provincia. Al iniciar su tarea de visitar los montes adscritos a su jurisdicción, muchas villas no colaboraron con él, de lo que se quejó en los siguientes términos.

«...lo es también la justa mortificación que me caussa el que vuestra señoría se persuada a que yo pueda dar lugar a inconvenientes ni quejas justas pues las que se an insignuado a vuestra señoria algunas republicas (que se comprenden en el distrito de la visita de montesque

jurisdicciones cortar árboles de los montes de la jurisdicción de Hernani, necesarios para la construcción de dos galeones ofrecidos por esta Villa. Año 1618.

202 AMN, Colecc. Vargas Ponce, Tomo XXII, Doc. 42, fol. 89. «Real Cedula del rey $\mathrm{D}^{\mathrm{n}}$. Phelipe $4^{\circ}$. Su fecha en Madrid 5 de Enero de 1647 por la qual da S.M. à la Prov ${ }^{\mathrm{a}}$. expresivas gracias por hauerle seruido con cantidad de Maderamen para la Fabrica de la Capitana Real que se construio en los Astilleros de la Villa de San Seuastian».

${ }^{203}$ Soria Sesé, L., Derecho municipal guipuzcoano. Categorías normativas y comportamientos sociales, Ob. Cit., p. 261. Cita A.M. Villa. A.7.1.7. 
me toca hacer) son sin fundamento alguno y opuestas a la execucion de las ordenes de su magestad porque sauida la repressentacion que han hecho a vuestra señoria se reduce a que no deuo dejar repartimiento de plantios entre los particulares vecinos d'ellas sino solo en lo concejil juzgando que lo demas es rigor y querer extender la jurisdicion de mi oficio... $\rangle^{204}$.

Sus requerimientos no surtieron efecto y diez años más tarde, este comisionado aún continuaba lamentándose de que las Juntas Guipuzcoanas no le habían remitido los testimonios de las villas sobre los plantíos hechos en la visita de la década anterior ${ }^{205}$.

A pesar de los intentos de las Superintendencias, la falta de fomento en el cantábrico llevó a que posteriormente fuera promulgada para la provincia de Guipúzcoa, con fecha de 11 de abril de 1670, una nueva de norma forestal antes citadaque no mencionaba las figuras de los superintendentes, pero entraba en su ámbito competencial respecto de las villas en las que se extendía el territorio bajo su jurisdicción. Bajo el epígrafe de «Conservación de los Montes, so penas graves» ${ }^{206}$, se contemplaba como una de las causas del deterioro de los montes la fábrica de navíos, si bien se reconocía igualmente la necesidad de continuar su construcción. Según expresaba la propia disposición, el espíritu que en ella subyacía era el de siempre; pero que difícilmente se había venido alcanzando, es decir, lograr una situación de equilibrio a través de la cual en los montes guipuzcoanos «se tenga cuidado en su mayor fomento posible» con el objetivo de lograr la «conservacion para material de los astilleros de los buques, herrerías y otras aplicaciones».

La norma partía de la base de que la situación de los montes de la región era manifiestamente mejorable, enunciando que «Descuidos de los últimos tiempos exigen tanto mas este cuidado». La causa de tales desmanes quedaba declarada expresamente en el texto, al entender que el motivo del menoscabo de los bosques se debía a la concurrencia de las actividades que giraban alrededor de los montes, por «hacer rozaduras y sementeras», lo que originaba enfermedades en los árboles dañados al formarse una capa de mala calidad como secuela del desprendimiento de la corteza. Por ese motivo, éstas eran prohibidas obligándose a todo particular que desease llevar a cabo dicha rozadura a la obtención de una licencia, expedida por «la autoridad del pueblo». Ahora bien, no se permitía que la institución municipal otorgase arbitrariamente la licencia para rozar, sino que ésta había

204 Aragón Ruano, A., El bosque guipuzcoano en la Edad Moderna: aprovechamiento, ordenamiento legal y conflictividad, Ob. Cit., p. 165. Cita Memorial de 1 de mayo de 1669 en A.G.G.-G.A.O., JD IM 2/17/12.

205 Aragón Ruano, A., El bosque guipuzcoano en la Edad Moderna: aprovechamiento, ordenamiento legal y conflictividad, Ob. Cit., p. 165.

${ }^{206}$ Recogida en la compilación efectuada por Soraluce, N., Fueros de Guipúzcoa. Títulos adicionales y consideraciones, reglamentos, sumario histórico, etc., Ob. Cit. 
de devenir como resultado de un procedimiento establecido por la norma y consistente en la elaboración de un «prévio informe de dos peritos» designados por el propio Ayuntamiento. De no seguirse este trámite, el condenado «pagará a cada uno 100 ducados de multa, y será además residenciado el Ayuntamiento ó particular que infrinja». Para lograr una relación fidedigna de la expedición de licencias se imponía un requisito consistente en que cada pueblo llevase nuevamente un registro exhaustivo de las mismas y de otros acontecimientos e incidentes que pudieren resultar de interés en materia forestal, por lo que «cada pueblo tendrá un libro en que se asienten las licencias concedidas, indicando con claridad las topografías de dichos puntos y otras circunstancias».

Las obligaciones del vecino que hubiere obtenido licencia no acababan ahí puesto que permanecía sujeto a efectuar una serie de labores que eran detalladas aseverando que «queda obligada por cada fanega de tierra rozada á plantar anualmente, mientras continúe sembrando en dicho punto, seis árboles castaños ó robles en la jurisdiccion del mismo pueblo donde éste mejor crea. Cada fanegada de sembradío equivaldrá la postura de cien manzanos, distante 10 codos uno de otro, y la plantación anual de dichos seis árboles se hará á la vez que la rozadura y sementera».

Por otra parte, esta nueva disposición establecía otra serie de obligaciones de carácter fiscal por parte de los pueblos a los vecinos de las poblaciones guipuzcoanas, que no eran en ningún caso especificadas y de las que tan sólo se hacía referencia a la necesidad de contribuir con «algún pequeño tributo destinado para plantíos de árboles», además de realizar visitas consistentes en reconocimientos «de las rozaduras hechas, segun se ordena en esta Ley; y si se observare que hubo antesplantíos en los puntos de las rozaduras, se harán nuevas plantaciones ${ }^{207}$.

A pesar de su contenido, pocos años más tarde, en 1674, la Monarquía se vio obligada a recordar que debían guardarse las normas que pretendían preservar ciertas masas forestales de la Provincia, impidiendo la tala de sus montes, tal y como consta en la siguiente orden de la Corona:

«La Reyna Governadora $=$ Junta Procuradores Caualleros hijos dalgo de la M. N. y M. L. Prouincia de Guipuzcoa. Ase me dado cuenta de que los Montes francos del valle de la Urumea poseidos por la Ciudad de San Seuastian y las Villas de Ernani y Urnieta en comunidad con los Vecinos de Dueños tratan de talarlos por el pie indistintamente sin hacer separacion en dejar las guias y reserbas conbenientes para corbatones ligazones barengas pies de genomas horquillas tablazón y madera dra'. y de otros jeneros, que precisamente son necesarios para las fabricas de Galeones y navios, que de no acudirse al Reparo quedaran extinguidos y germados [i "merma-

207 Soraluce, N., Fueros de Guipúzcoa. Títulos adicionales y consideraciones, reglamentos, sumario histórico, etc., Ob. Cit. 
dos"?] los Montes con tal destrucción sin esperanza de que Vuelvan a su primer ser y las fabricas sin Recurso a tantos materiales como necesitan y se podran lograr de dhos Montes mayormente quando las que a hauido en los años antecedentes han consumido tan gran numero de Materiales, que obliga para la fabrica de la Capitana Real y de otros Galeones buscarlos y conducirlos ocho y diez leguas la Tierra adentro y siendo esta materia en que tanto interesa el Servicio del Rey mi hijo a parecido mandaros (como lo hago) deis las Ordenes necesarias a estas tres Republicas y sus Justicias, que en ninguna manera se permita la tala de los dhos montes dexandolas sazonar para que corriendo el Corte en la forma que deue ser bayan dexando las Reserbas y guias en toda perfeccion para que haya los materiales referidos y bayan en aumento en el mayor numero, que ser pudiere guardando las leyes y ordenes que sobre ello eran dadas precisa y imbiolablemente a que atendereis con el Celo que acostumbrais y de los que dispusieredes, y se executare me dareis quenta $\rangle^{208}$.

La disposición es elocuente puesto que la reiteración de peticiones para preservar a foresta continuaba siendo síntoma de un incumplimiento generalizado de las órdenes de la Monarquía.

\subsection{Efectos en el bien jurídico a proteger: agotamiento de las masas forestales}

En todas estas pugnas, por lo general hubo un protagonista perjudicado, tanto por una como por otra parte, el bosque. Los poderes políticos eran absolutamente conocedores de su trascendencia económica ${ }^{209}$. Sin embargo, como acabamos exponer, buena parte de la cubierta vegetal leñosa del arco cantábrico llegó a estar esquilmada. Éste no fue un fenómeno propio de los últimos años de la dinastía de los Austrias ni tampoco podemos decir que se produjese en todos los lugares por igual. A pesar de esta falta de homogeneidad, a la vista de la documentación consultada algo sí parece claro: desde los comienzos de la construcción naval a gran escala ya se vinieron produciendo quejas acerca del deterioro de montes septentrionales en la Península. Desgraciadamente, no disponemos de ningún tipo de cartografía histórica que nos permitiese evaluar con precisión la magnitud de los daños en la cubierta vegeta ${ }^{210}$. Ahora bien, sí resulta claro que la sobreexplotación logró degradar un bien, el Monte, que era la base de las principales actividades económicas

${ }^{208}$ AMN, Asuntos diversos de Marina, Ms., 580 (fol. 23 r.-23 v.). Orden de la Reina Gobernadora, Madrid, 8 de abril de 1674.

209 Urteaga, L., La tierra esquilmada. Ideas sobre la conservación de la naturaleza en la cultura española del siglo XVIII, Ediciones del Serval S.A., Barcelona y C.S.I.C., Madrid, 1987, p. 115.

210 Ibídem. 
de la época, constituyendo «la causa primera y más importante en orden al quebranto de la riqueza patrimonial de los municipios $»^{211}$.

Este menoscabo era fundamentalmente consecuencia de los excesos cometidos en las cortas masivas y, aunque éstas no sólo fueron resultado de la acción de las Superintendencia, sí es cierto que los superintendentes tuvieron mucho que ver en la degradación de la masa arbórea. Grandes extensiones de terreno quedaron yermas durante mucho tiempo, pues a pesar de la política de plantíos, se taló durante toda la vigencia de la institución más de lo que se iba regenerando. Las palabras de uno de ellos, Idiáquez, fueron elocuentes: «un roble ha menester 80 años para que del se pueda sacar tabla»y, a pesar de los esfuerzos hechos en materia de repartimientos y recuperación no se lograba dar abasto a tanta demanda maderera, porque «esto no puede suplir lo que se ha cortado $»^{212}$. Ello incluso obligó en ocasiones a aumentar de facto el radio de acción de la Superintendencia en Guipúzcoa hasta cinco o seis leguas del litoral marítimo, a pesar de que ya sabemos que las instrucciones de la Monarquía sólo habilitaban por lo general la distancia comprendida entre las dos leguas cercanas a la costa o a ríos navegables. Según su experiencia, el propio Idiáquez sólo encontraba como solución impulsar lo que anunciaba como otras técnicas de plantaciones:

«...hallo q combiene ordenar que todas las villas de sus propios, hagan riberos grandes sembrando bellota, y habiendolos echo en aber ellos mismos estaran obligando a que los trasplanten al cabo de seis años q los plantones estaran sazonados, y este remedio es facil y fiable $\mathrm{y}$ en beneficio de los mismos naturales y bastante $\mathrm{p}^{\mathrm{a}}$ cubrir la tierra $\mathrm{q}$ ay en aquellas partes $\rangle^{213}$.

Pero las sugerencias del superintendente guipuzcoano siempre se quedaron en eso, en meras propuestas que nada hicieron cambiar lo que venía siendo el mismo modo de proceder desde los tiempos de Cristóbal de Barros. Este mismo llegó a esquilmar enormes áreas a causa de los encargos navales que le hacía llegar la Monarquía. La tónica continuó tras su cese y fueron constantes las dificultades que la institución encontró para lograr abastecer de maderas aptas al Real Servicio. Aún no había expirado el siglo XVI cuando el superintendente en Guipúzcoa, Antonio de Urquiola se vio obligado a explicar a Felipe II que para la fábrica de seis galeones en el puerto de Pasajes, a pesar de haber contratado «a todos los oficiales que sauen serrar y hazer tabla» resultaba muy complicado «buscar la madera que fuere ne$\operatorname{cess}^{0} »$ porque «la mayor y mejor parte de la que hauia en esta Comarca se a

211 Soria SesÉ, L., Derecho municipal guipuzcoano. Categorías normativas y comportamientos sociales, Ob. Cit., p. 254.

${ }^{212}$ AGS, G.A., Leg. 3157. Carta de Idiáquez a Felipe IV, 30 de enero de 1631.

213 Ibídem. 
gastado y consumido en la fabrica de los galeones que se han hecho antes» ${ }^{214}$. Las quejas del oficial no eran infundadas, pues Odriozola Oyarbide cita, por ejemplo, cómo entre 1593 y 1594 se cortaron 400 robles en los montes de Rentería para la construcción de seis navíos, cantidad que la autora estimaba que debió ser mayor a pesar de no disponer de datos, pues desde el primero de estos años hasta 1597 la actividad de los astilleros guipuzcoanos, especialmente los renterianos, $\mathrm{y}$, en menor medida, de los vizcaínos, fue especialmente productiva, llegando a construirse en esta población un total de veintinueve galeones para las Armadas Reales ${ }^{215}$.

Por su parte, el Capitán Agustín de Ojeda, quien más tarde sería Superintendente en la costa vizcaína, tomó parte en aquella deforestación, dejando relación de maderas cortadas y reflejando la reticencia de la población local a participar de la corta sin mediar compensación económica, puesto que:

«...quando bine a esta Villa [Rentería] a principiar esta fabrica tomando platica delos montes della alle que no abia otro mas acomodado que un exido que tiene la misma Villa, que es el mejor que ay en toda esta provincia y tratando con la Justicia y regimientos della se hauia de cortar madera en el, no quisieron que se començasse sin obligarme a la paga y por facilitar el seruicio de V.m ${ }^{d}$. y que no sse ynquietasen lo hize mediante esto sean cortado como quint ${ }^{\mathrm{s}}$. arboles, y sera menester cortar mas de otros cuatrocientos y últimamente no queria ya cortar ninguno hasta que se les pagase lo que se auia tomado con buenas palabras ofreciendoles que del primer dinr ${ }^{0}$. que V.m ${ }^{\mathrm{d}}$. mandase enviar se les pagaria ${ }^{216}$.

Si los montes guipuzcoanos sufrieron un enorme desgaste por parte de los comisionados regios se debió a que esa zona del litoral fue clave en la política de fomento naval y así continuó a lo largo del siguiente siglo, ya que en ella había concentrados tres astilleros principales al servicio del monar$\mathrm{ca}^{217}$. En efecto, el mayor peso tanto constructivo como forestal recayó en la mitad oriental del Cantábrico donde existieron presiones para preservar y fomentar maderas a favor de la Armada, llegando a producirse frecuentes

${ }^{214}$ AGS, Leg. 484-54. Carta de Antonio de Urquiola a Felipe II, Pasajes, 25 de abril de 1597.

215 Odriozola Oyarbide, L., «La construcción naval en Guipúzcoa. Siglos XVIXVIII» en Itsas Memoria. Revista de Estudios Maritimos del País Vasco, nº. 2, Ob. Cit., pp. 111-112.

${ }_{216}$ AGS, G.A., Leg. 406-221. Agustín de Ojeda a Felipe II, Rentería, 24 de octubre de 1594. Aragón Ruano, A., El bosque guipuzcoano en la Edad Moderna: aprovechamiento, ordenamiento legal y conflictividad, Ob. Cit., p. 47.

217 Odriozola Oyarbide, L., Construcción naval en el País Vasco, siglos XVI-XIX. Evolución y análisis comparativo, Diputación Foral de Gipuzkoa, Departamento de Economía y Turismo, San Sebastián, 2002, p. 107. 
disensiones ${ }^{218}$. Siempre se precisaron navíos en la costa vasca y los materiales necesarios debían acapararse con prontitud en los bosques aledaños ${ }^{219}$. En 1594, el propio Agustín de Ojeda tuvo ocasión de requisar toda la tabla seca que había hallado en la costa para la construcción de seis navíos ${ }^{220}$. Dos años más tarde, dijimos que debido a la enorme demanda, la Provincia se vio obligada a proveerse de maderas navarras, cuyas masas forestales no estaban tan explotadas como en las áreas vascas ${ }^{221} \mathrm{y}$, de acuerdo con los Fueros de aquel Reino, se permitió la exportación de troncos y tablazón con destino Guipúzcoa para fábrica de navíos ${ }^{222}$.

218 Odriozola Oyarbide, L., «La construcción naval en Guipúzcoa. Siglos XVIXVIII» en Itsas Memoria. Revista de Estudios Marítimos del País Vasco, nº. 2, Ob. Cit., p. 93. Afirma que en todos los puertos de aquella provincia, excepto Guetaria, habían instalados astilleros de diferentes tamaños, durante los siglos XVI y XVII.

219 En aquel mismo año, el 23 de agosto de 1597, fue emitida una Real Cédula a don Juan Velázquez, capitán general de la provincia de Guipúzcoa, enviándole una relación sobre las naos más convenientes en la navegación a Indias y para que informase acerca de su fabricación, que apremiaba, después de consultarlo con Antonio de Urquiola. En el mismo documento se establecía un mandato análogo para el corregidor de Vizcaya, quien debía tratar este asunto con el arriba citado, capitán Agustín de Ojeda. AGI, Indiferente, 1957, L.5, f.50v.

${ }^{220}$ AGS, G.A., Leg. 427-97. Carta de Agustín de Ojeda a Felipe II, Rentería, 15 de mayo de 1595.

${ }^{221}$ Soria Sesé, L., «Bienes comunales en Navarra y las Provincias vascas (siglos XVI-XVIII)» en Historia de la Propiedad en España. Bienes comunales, pasado y presente, Ob. Cit., p. 105.

222 De Elizondo, J., Edición de la Novissima Recopilación de las Leyes del Reino de Navarra hechas en sus Cortes Generales desde el año de 1512 hasta el de 1716 inclusive. Año 1735. Vol 2. Editorial Aranzadi, Pamplona, 1964, pp. 92-93. Lib. I, Tít. XVIII, Ley XLIII dice así: [Pamplona. Año 1596. Ley 62] «No es de menor consideración el daño que reciben los naturales deste Reino, que residen en las Montañas de una novedad, que ahora se hace por los Soldados, que en los confines de Francia están en Vera, y en Maya, estorbando, que no se lleve madera, ni otra tablazón á Guipúzcoa. Porque de las pocas grangerias que en las dichas montañas se ofrecen, una de ellas es hacer votas, y pipas, que sirven para portear por la mar el vino, que se embarca para las Indias, y otras partes: y también la clavazon, y otras cosas semejantes. Demás, que se llevan á Guipúzcoa maderas para la fabrica de los Navios, que en aquellas costas se hacen, por no hallarse en ellas tal aparejo. Y todo se hace en este Reino de arboles caídos, ó infructiferos. Y quando fuessen cortados de nuevo se havia de permitir: lo uno por el gran provecho que de ello resulta, por el bien comun de tantos Reinos de vuestra Magestad, á donde se llevan las obras susodichas; y lo otro por evitar la falta que de lo contrario se seguiria; y lo otro por el provecho, que los Naturales deste Reino reciben de ésta grangeria. Y también porque por el daño que reciben de ésta prohibicion, los Guipuzcoanos prohibirán también ellos (como han comenzado á hacerlo) el traer de su Provincia á este Reino, mena, y otras cosas que de allá se trahían: Demás, que tambien cessan muchos derechos, que la dicha obra se pagan á las Tablas Reales de vuestra Magestad. Y aunque los dichos Soldados podrían haver tenido ocasion para hacer esto en las instrucciones, que llevan del Ilustre vuestro Visso-Rey deste Reino, que deben decir no dexen passar cosas de madera nunca se há entendido, ni practicado, sino en respecto de Francia, y en respecto de aquel Reino se ponen por Guardas los dichos Soldados, y no en respecto de Guipuzcoa. Y por esso sin embargo de las dichas 
Las pugnas con los dueños particulares en defensa de sus árboles siempre fueron generalizadas. Idiáquez, al enviar una relación de mástiles de pino hallados en Rentería, informó que eran constantes los desencuentros con los propietarios de terrenos en Oyarzun por razón de no aceptar los precios que él les ofrecía en la compra de sus árboles. A pesar de ello las labores continuaron y con afán de poder seguir recabando maderas solicitó a la Corona la compra de "unos montes muy buenos que tendrán mas de 100 mil codos de madera y se daran por poco mas de 4 mil des por que se venden por deudas y seria bien comprarlos para su $\mathrm{M}^{\mathrm{d}}$. pues por $12 \mathrm{mil} \mathrm{de}^{\mathrm{s}}$ no se hallarían otros tales", que se encontraban cercanos a la factoría de Lezo ${ }^{223}$. Aún así, la madera de la provincia era tan escasa que no resultaba suficiente, por lo que se vio obligado a encargar una remesa de 195 piezas de arboladura, para fabricar mástiles de diferentes tamaños y grosores desde Noruega ${ }^{224}$.

Ninguna de las normas o medidas adoptadas por los superintendentes parecieron poder regenerar los bosques de aquellos territorios al ritmo que los astilleros necesitaban, a pesar de que la subsistencia de sus poblaciones giraba alrededor de la madera.

\section{CONCLUSIONES}

La investigación nos ha llevado a tomar como punto de partida, al margen de algunos antecedentes expuestos, la segunda mitad del siglo XVI porque la gestión maderera para navíos de guerra comenzó su curso en grandes cantidades a partir de aquel momento. Más concretamente hemos debido analizar la figura de un personaje prácticamente desconocido pero absolutamente trascendental para comprender la base de los engranajes jurídicos, institucionales y de gestión del poder naval filipino, sobre el que recaía buena

instrucciones, que han llevado los otros años los Soldados, que en los dichos Puertos han residido, se han passado publicamente á Guipuzcoa las dichas obras, y madera, y conviene que se passen para el servicio de vuestra Magestad, y bien de éste Reino, por las dichas razones. Porende pidimos, y suplicamos á vuestra Magestad, ordene, y mande, que los Soldados que residen en los dichos Puertos, ni otras personas, no estorven de aqui adelante el passar á Guipuzcoa madera, ni obra que de ella se haga, que en ello, \&c. [Decreto] $A$ esto os respondémos, que por contemplacion del Reino se dá licencia á todos, para que puedan libremente llevar, y passar tablas, y maderas para la Provincia de Guipuzcoa á otros Reinos, y Señoríos nuestros, con que al passar los registren en el postrer Lugar del Puerto por dodne las passáren, y traigan testimonio autentico del Lugar donde las huvieren dexado, y lo dexen á la persona ante quien huviere hecho el registro, y la tal persona de seis á seis meses embie á nuestro Visso-Rey la razon de lo que huviere passado, y de los testimonios, que le huvieren dado». Aragón Ruano, A., El bosque guipuzcoano en la Edad Moderna: aprovechamiento, ordenamiento legal y conflictividad, Ob. Cit., p. 119.

${ }^{223}$ AGS, G.A., Leg. 726. Carta de Domingo de Idiáquez a Felipe III, Azcoitia, 2 de septiembre de 1609 .

${ }^{224}$ AGS, G.A., Leg. 726. Relación Domingo de Idiáquez, Azcoitia, 29 de julio de 1609. 
parte de la política exterior protagonizada por la Monarquía Universal: Cristóbal de Barros y Peralta.

El por qué de esta decisión ha sido claro. Como hemos tenido ocasión de comprobar, la premura de la Monarquía Universal por señorear los mares, propició la aparición de una institución, protagonizada por aquel comisionado, que sirvió para gestionar y explotar aquella fuente de riqueza natural que eran los bosques, también codiciadas por diferentes sectores de la sociedad e íntimamente vinculada a extensas áreas vizcaínas y guipuzcoanas. No en vano, para las poblaciones de aquellos montes ubicados a dos leguas de la mar o ríos navegables la funcionalidad de árboles se basaba en todo un elenco de posibilidades, como la obtención de energía, alimentación del ganado y recolección de materiales diversos. Estos usos se integraban en cada territorio debiendo guardar un cierto equilibrio, pues de lo contrario el sistema en conjunto corría peligro: la explotación excesiva implicaba una deforestación, que a su vez suponía menores disponibilidades de pastos, de ganado, de abono y de energía, que podían traer consigo situaciones de pobreza o hambruna ${ }^{225}$.

Consecuentemente, la aparición en el reinado de Felipe II de una nueva jurisdicción que se ocupase de los asuntos silvícolas, la Superintendencia de Montes y Plantíos, supuso una alteración de los derechos de las poblaciones locales, hasta entonces tradicionales, sobre los bienes producidos por los bosques, casi siempre en favor de las necesidades exteriores/marítimas pretendiendo desde entonces ser gestionados sin depender de las Juntas y municipios vascos, sino únicamente por agentes de la Corona o de otros órganos vinculados directamente a la misma.

En conclusión, las posturas fueron antagónicas, debido a que aquellas necesidades sociales, por un lado, y navales, por otro, no eran otra cosa que el reflejo de dos mundos: por un lado, un universo silvícola habitado por sociedades rurales en las que sus instituciones locales, de estructura y administraciones con pervivencia medieval, eran las más próximas al campesinado. Frente a ellas una política de arbolados, protagonizada por los comisionados regios, que intentó sobreponerse a aquellas formas de gobierno provenientes de siglos anteriores y que terminó frecuentemente colisionando, con derechos provinciales o locales. Mediante este nuevo régimen de Montes la Monarquía Hispánica no pretendió hacerse con el control y explotación de todas las masas boscosas sino de las más codiciadas para la construcción de barcos, las del norte peninsular, cuyo arbolado tenía una calidad que resultaba estratégica para la política naval de la Corona. A pesar de los inconvenientes, las necesidades marítimas pretendieron imponerse frente a las de las economías locales y ello generó un problema, con connotaciones políticas y estratégicas,

225 Iriarte GoÑI, I., «La funcionalidad económica y social de los montes. Un esbozo de las transformaciones de largo plazo» en Actas de la II Reunión sobre Historia Forestal. Cuadernos de la Sociedad Española de Ciencias Forestales, n 16, Valladolid, 2003, pp. 32-33. 
que resultaba insoslayable ${ }^{226}$ : el agotamiento de los bosques. Por lo general, se taló más de lo que crecía y la Corona tuvo que plantear el control, la conservación e incluso la repoblación de las masas forestales. Sin embargo, de poco sirvió pues la documentación consultada demuestra que, a pesar de los esfuerzos, los árboles frecuentemente escasearon. Por este motivo, estamos de acuerdo con Goodman, cuando considera que «la construcción de barcos, razón principal de la política conservacionista, era al mismo tiempo una causa principal de deforestación $»^{227}$.

En definitiva, la conflictividad institucional, debida a las variedades e indefiniciones jurisdiccionales ${ }^{228}$, resultó patente a lo largo de toda su historia. Los desencuentros fueron más frecuentes que los encuentros. Las entidades de carácter local o regional eran con asiduidad representantes de unas economías e intereses vecinales que también codiciaban la explotación silvícola, y protagonizaron importantes fricciones con los agentes del rey e incluso llegaron a impedir, con más constancia de la que éstos hubiesen deseado, las tareas que les habían sido encomendadas por parte de la Monarquía. Como hemos tenido ocasión de comprobar, la publicación reiterada de normas con igual contenido es reflejo de esto. No obstante, ello no siempre representó una negativa frontal de esas instituciones a colaborar con las necesidades de la Corona; antes al contrario, en ocasiones fueron estas mismas, como por ejemplo las Juntas Generales vascas, las que se ofrecieron puntualmente a asistir al rey en materia de cortas y plantíos, pero siempre pretendiendo pasar por alto las competencias de los comisionados de la administración central de la Monarquía.

\begin{abstract}
RESUMEN: Este estudio pretende analizar, desde una perspectiva juridico-institucional, la pugna entre, por un lado, los requerimientos de la Monarquía de los Habsburgo por explotar los bosques vizcaínos y guipuzcoanos para abastecer de maderas a las Armadas que preservaban los extensos territorios hispánicos. Por otro, las necesidades de las poblaciones rurales, gestionadas por derechos propios basados fundamentalmente en la costumbre, que se sustentaban en los bienes que los árboles les proporcionaban, y fueron defendidas frente a los comisionados reales por sus instituciones locales o provinciales.
\end{abstract}

Palabras ClaVE: Austrias, Marina, Montes, Vizcaya/Bizkaia, Guipúzcoal Gipuzkoa.

226 Giménez I Blasco, J., «La qüestió forestal a Catalunya. Les ordinacions de 1627» en Actes. Primer Congrés d'Història Moderna de Catalunya, Vol. 1., Universitat Barcelona, Barcelona, 1984, p. 246.

227 Goodman, D., El Poderío naval español. Historia de la Armada del siglo XVII, Ob. Cit., p. 120.

${ }_{228}$ Aragón Ruano, A., El bosque guipuzcoano en la Edad Moderna: aprovechamiento, ordenamiento legal y conflictividad, Ob. Cit., p. 165. 
TITLE: Forest management, naval need and legal-institutional conflict: the Hispanic monarchy and the Basque institutions during the Habsburgs.

ABSTRACT: The aim of this study is to analyze, from a legal and institutional perspective, the conflict between, on one hand, the requirements of the Habsburg Monarchy by taking advantage of Bizkaia's and Gipuzkoa's forests to supply wood to the Navy that preserved the extensive Hispanic territories. On the other hand, the needs of rural populations, managed by inherent rights mainly based on customs, which were sustained with the consumer goods that the trees provided them, and were defended against the royal commissioners for their local or provincial institutions.

KEYWORDS: Habsburgs, Navy, Forest, Biscay, Gipuzkoa.

Recibido: 10.04.2013

Aceptado: 09.05.2013 